\title{
EURÓPAI INTEGRÁCIÓ, KELETI BŐVÍTÉS ÉS A MAGYAR REGIONÁLIS POLITIKA
}

\section{(Enlargement of the European Union and the Hungarian Regional Policy)} HORVÁTH GYULA

\author{
Az Európai Unió kohéziós és strukturális politikája
}

\section{A reformfolyamatok}

A makrogazdaságok összehangolására létrejött Európai Közös Piac politikájában az európai gazdaság fejlődésében bekövetkezett gyökeres változások és az integráció bövülésével párhuzamosan - a tagállamok és az egyes országokon belüli téregységek közötti kohézió erösitése fokozatosan került elöre a prioritási rangsorban. A regionális politika stratégiai jelentőségét mutatja, hogy az e célra forditott közösségi kiadások 1975-ben a költségvetés 4,8\%-át, 1988-ban 8,1\%-át tették ki, a strukturális mūveletekre forditott pénzeszközök 1994-ben 31,3\%-os részarányt képviseltek, az 1999. évben pedig 35,7\%-ot tesznek majd ki ( 1 . ábra). A strukturális politika finanszírozása az 1990-es évtized végéig az Unió második legjelentősebb tételét jelenti. Az agrártámogatások és a regionális politikai források közti különbségek jelentösen mérséklödtek, a két feladatcsoport között húsz esztendő alatt 10:1-röl 1,3:1-re csökkent a költségvetési támogatás volumene.

\section{1. ÁBRA}

A regionális célú kiadások aránya az EU költségvetésben (\%)

(Share fo regional funds in the EU budget)

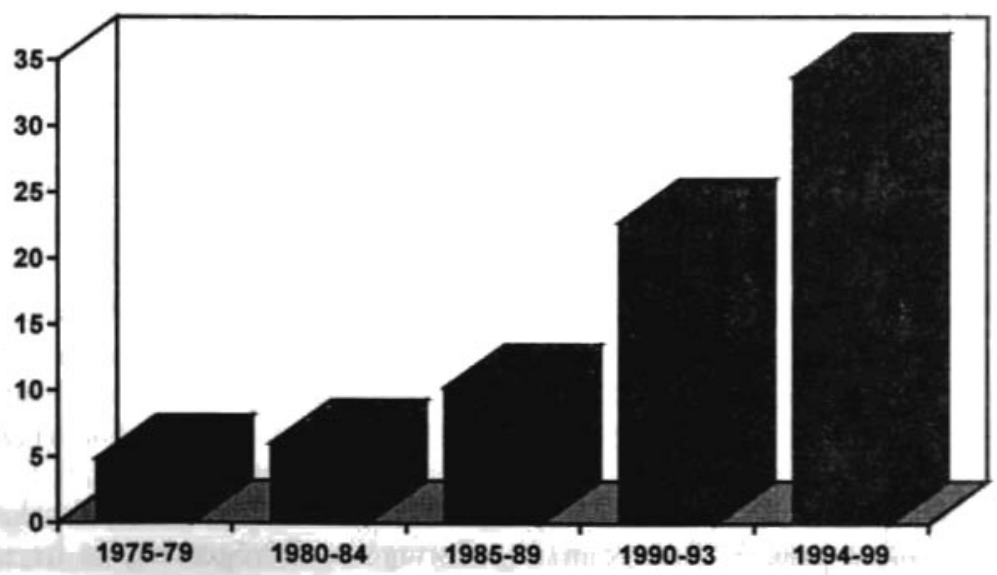

Forrás: Az Annual Report of the CEC (különbözō évek) alapjân szerkesztette: Horváth Gy. 
A regionális fejlesztések társadalompolitikai szerepét az húzza alá, hogy míg az agrártámogatások 10 millió mezögazdasági foglalkoztatott jövedelmi viszonyait, közvetve még kb. 50 millió fö életkörülményeit befolyásolják, addig a strukturális eszközök közvetlen vagy közvetett hatásait 186 millió közösségi lakos, az össznépesség fele érzékeli. E lényeges népességszám-különbség okozza az Unió költségvetésére nehezedö nagy nyomást, ami részben a globális finanszírozás folyamatos reformját, illetve az egyes feladatcsoportok belső müködésének hatékonyabbá tételét tartja folyamatosan napirenden.

A regionális politika századfordulóig érvényes mai eszközrendszere két reformsorozat eredményeit tükrözi. Az első reformcsomagot a két nyugatmediterrán ország belépése kényszerítette ki, a bövítés ugyanis 56\%-kal növelte a gyenge struktúrájú területeken élö népesség számát. Az 1987. évi Egységes Európai Okmány a regionális politikai eszközök hatékonyabb összehangolásának követelményét fogalmazta meg. A közösségi alapok 1988. évi reformjának lényege az erőforrásoknak a legsúlyosabb szerkezeti problémákra való összpontosítása volt.

A Strukturális Alapok müködésének átalakitása három alapcélt követett:

- a strukturális politikát tényleges gazdasági hatásokat kiváltó eszközökkel valósitsák meg,

- a tagállamok támogatását hosszú távú programokhoz kössék,

- a strukturális politika megvalósitásában résztvevő szereplök között szoros partnerkapcsolatok épüljenek ki, különös figyelemmel a regionális hatóságok és önkormányzatok koordinációs szerepére és a magánszféra pénzeszközeinek a bevonására.

A reform során az alábbi alapelvek érvényesültek:

- Szubszidiaritás és decentralizáció: önálló mozgástér, döntési kompetencia és finanszírozási eröforrások a különbözö méretü és jogállású területi közösségeknek belső eröforrásaik és a nemzeti stratégia összehangolásában;

- Partnerség: a különböző ágazati, tulajdonosi és eltérỏ tevékenységü szervezetek és intézmények területi fejlődésre hatást gyakorló döntéseinek intézményes koordinálása;

- Programozás: alulról építkező stratégiai és operatív tervezés, a legitimált stratégiákkal konform fejlesztési prioritások és támogatások, az egyedi projektfinanszírozást a komplex programok támogatása váltotta fel;

- Koncentráció és addicionalitás: jól elhatárolt fejlesztési térkategóriák, kombinált költségvetési és nem közösségi erőforrás-hasznosítás a gazdasági növekedést és a szerkezetátalakitást szolgáló ágazati prioritásokhoz rendelve.

A Strukturális Alapok második reformját az Európai Bizottság 1991. decemberi ülésén elfogadott II. Delors-reformcsomag indította el. A tagállamoknak az a felismerése, hogy a Közösségnek a szorosabb gazdasági és politikai egység irányába kell fejlödnie, azzal a megállapítással párosult, hogy a gazdasági konvergencia veszélybe kerülhet a gazdasági és a társadalmi kohézió erösítése nélkül.

A reformcsomag részeként $41 \%$-kal megemelték a strukturális kiadásokat, a legelmaradottabb országok (Spanyolország, Portugália, Görögország és Írország) támogatására létrehozták a Kohéziós Alapot, egyszerüsítették a döntési mechanizmust, a támogatások felhasználásának ellenőrzésére szigorú 
szabályrendszert dolgoztak $\mathrm{ki}$, és kisebb változtatásokat hajtottak végre a kedvezményezett ágazatok körét illetően (az elmaradott célcsoportba tartozó régiók egészségügyi és oktatási fejlesztési programjai is támogatásban részesíthetök). Jelentős - a koncentráció elvével nem összeegyeztethetö - változás volt viszont a kedvezményezett térségek körének bővítése. A nemzeti kormányok és az egyes régiók nyomására a kedvezményezett területen élő népesség száma 27\%-kal nött. Kelet-Németország elmaradott területté nyilvánításán kívül Belgium, az Egyesült Királyság és Franciaország növelte az elmaradott kategóriába sorolt területeit, Dánia és Olaszország pedig nagyobb részesedésre tett szert a depressziós térségeknek juttatott támogatásokból. Némiképp csőkkent viszont az egyéb országok iparilag hanyatló térségeinek száma.

A közösségi tervezési rendszer kétszintűvé alakult, a fejlesztési tervek és a megvalósítási programok egységes programozási dokumentumban (Single Programming Document) jelennek meg.

A regionális fejlesztési programok elfogadásának eljárási mechanizmusát egyértelmủ szabályok rendezték:

- a tagállamok összeállitják a támogatandó térségek fejlesztési programjavaslatait;

- a programtervezetet ègyeztetik az országos, a regionális és a helyi hatóságokkal;

- meghatározzák a Közösségtöl igénylendö kiegészitö források nagyságát;

- a programokat egyeztetik a közösség egyéb (versenypolitikai, környezetvédelmi, stb.) követelményeivel;

- részletes terv készül a közösségi alapok közti feladatmegosztásról és finanszírozásról;

- az egységes programozási dokumentum elfogadásáról az Európai Közösség Bizottsága dönt (a döntéselökészítésbe bevonja az állandó bizottságokat, meghatározó jelentőséget tulajdonítva a Régiók Bizottságának).

A koncentráció elvének érvényesülését jelzi, hogy az 1989-93 közötti időszak 1200 programjával szemben a jelenlegi hatéves tervezési periódus már csak 300 programot tart nyilván. Arányváltozások tapasztalhatók a támogatások ágazati felhasználásában is. Míg korábban az elmaradott térségekben az infrastruktúra-fejlesztési ráfordítások domináltak, a humán erőforrások és a termelés fejlesztése csekélyebb súllyal szerepelt, ma az iparfejlesztésre fordított források aránya a legmagasabb. Hasonlóképpen alakul a depressziós térségekben felhasznált fejlesztési erőforrások megoszlása is (2. ábra).

$\mathrm{Az}$ 1995. évi bövülés - az újonnan tagállamokká lett országok viszonylag kis mérete, fejlett piacgazdasága miatt - nem igényelte a közösségi regionális politika jelentősebb módositását, csupán a ritkán lakott észak-skandináviai térségek számára hozták létre a 6. támogatási célcsoportot. Ausztria, Finnország és Svédország területfejlesztési támogatásai összesen 4,1 milliárd ECU-t tesznek ki, 8,1 milliós népességet érintenek. A területfejlesztési támogatásban részesülö népességszám csak 4,5\%-kal emelkedett. A bővülés eredményeképpen az Unió elmaradott térségeinek száma csupán Burgenlanddal gyarapodott, a 270 ezer lakosú tartomány ơt esztendőre 162 millió ECU támogatásban (a Közösség összes elmaradott térségére jutó támogatás $0,17 \%$-ával) részesül. 


\section{2. ÁBRA}

A támogatások felhasználása föbb tevékenységek szerint a) Elmaradott térségek

(Utilisation of EU funds by the fields of activities)

1989-93

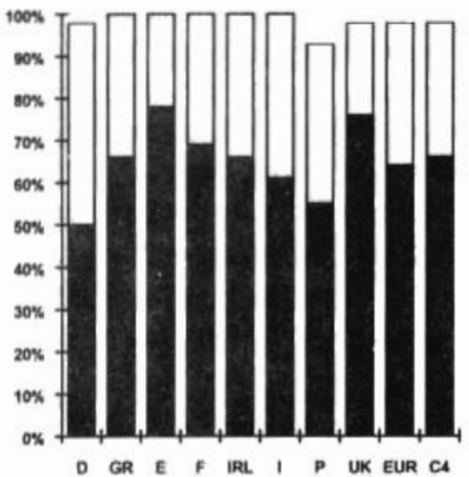

1994-99

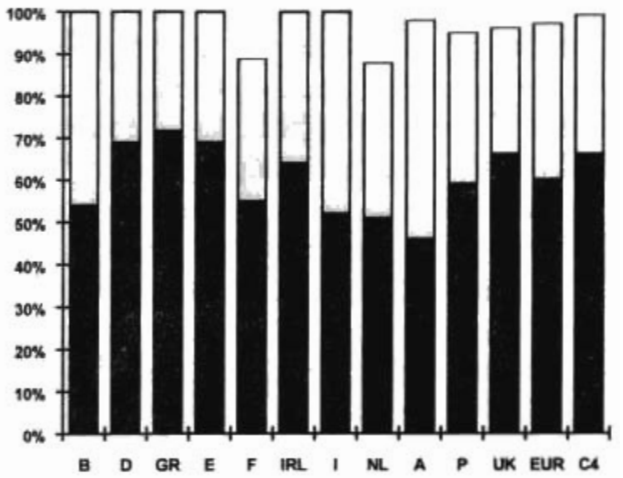

E Infrastruktúra

- Emberi erōforrások $\square$ Termelési kōmyezet

Forrás: First Report on Economic and Social Cohesion. p. 92.

b) Iparilag hanyatló térségek

1989-93

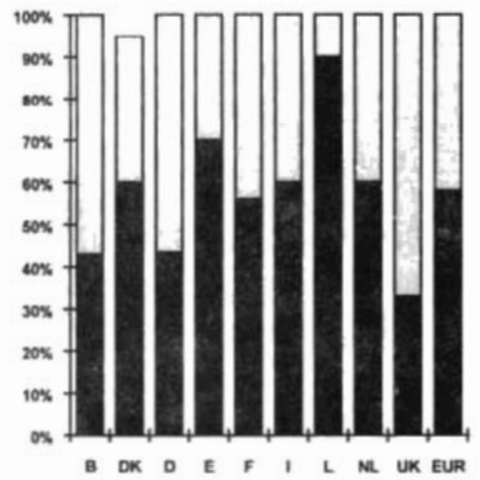

1994-96

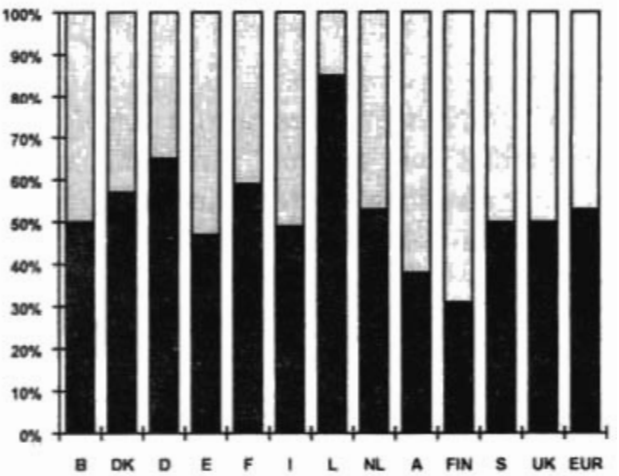

- Terulletrendezós

- Emberi erōforrások $\square$ Termelési környezet

Forrás: First Report on Economic and Social Cohesion. p. 93. 
c) Rurális térségek

1989-93
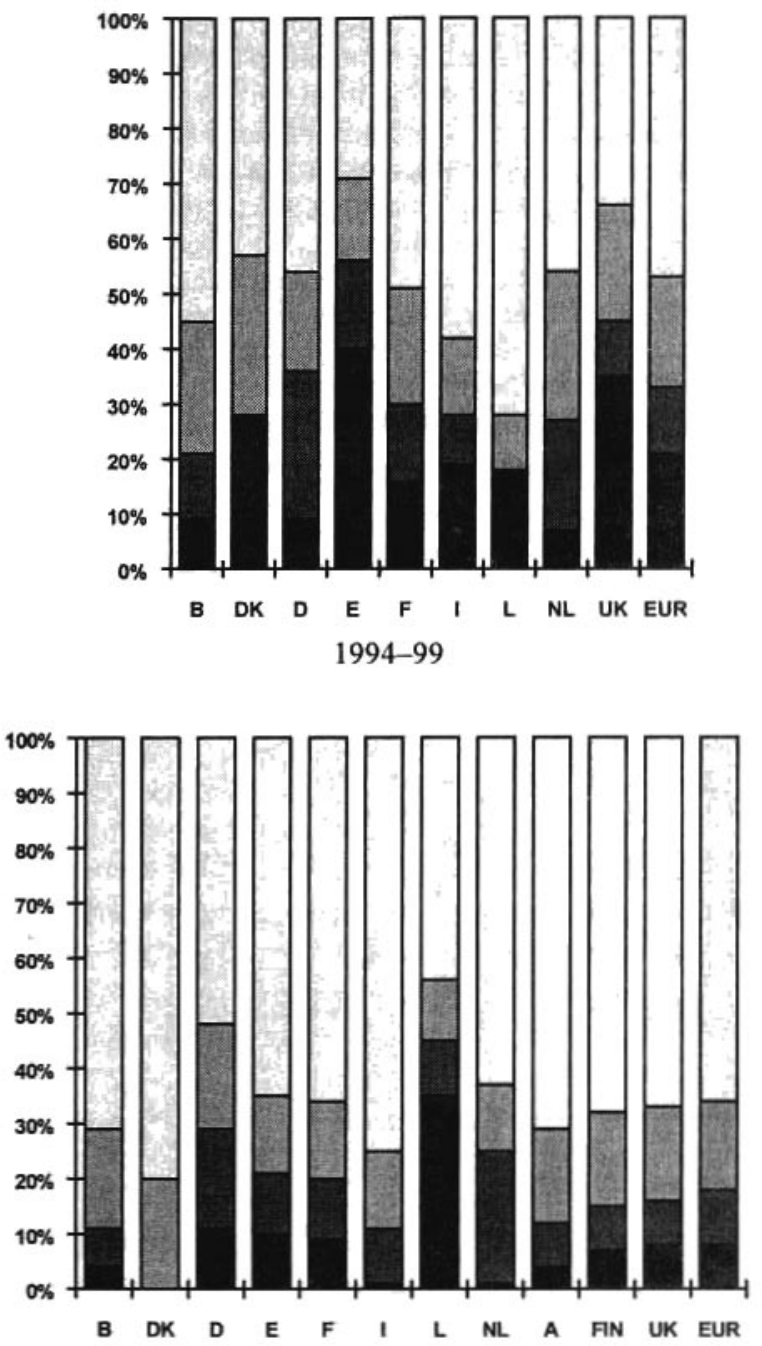

Forrás: First Report on Economic and Social Cohesion. p. 94. 


\section{A régiók közötti kohézió}

A tagállamok között megmutatkozó jelentös különbségekkel párhuzamosan lényeges eltérések figyelhetők meg a Közösség centrum- és periférikus régiói között is. A Földközi-tenger és az Atlanti-óceán menti régiók, a kelet-németországi, az észak- és kelet-finnországi területek gazdasági teljesítőképessége a közösségi átlagok alatt marad.

A legfejlettebb és a legfejletlenebb régiók között jövedelmi különbségek a 80-as évtizedben csak csekély mértékben mérséklödtek. Az Unió leggazdagabb (a német Hamburg Land) és a legszegényebb (a portugál Azori-szigetek) régiójának egy före jutó GDP-je között 1983-ban 4,7-szeres, 1993-ban pedig 4,5-szörös volt a különbség (3. ábra). A legfejlettebb és a legfejletlenebb 25-25 régió jövedelmi differenciái egy évtized alatt nem csökkentek, és a két csoportot alkotó régiók sem változtak. A kohéziós politika szükségességét indokolja, hogy az Európai Unióban tapasztalható regionális különbségek átlagai kétszer magasabbak, mint az Egyesült Államokban. A kelet-európai bỏvülés a differenciákat tovább mélyíti.

\section{3. ÁBRA}

Az egy före jutó GDP regionális különbségei a tagállamokban, 1993

(Regional differences of GDP/capita in the EU-member states, 1993)

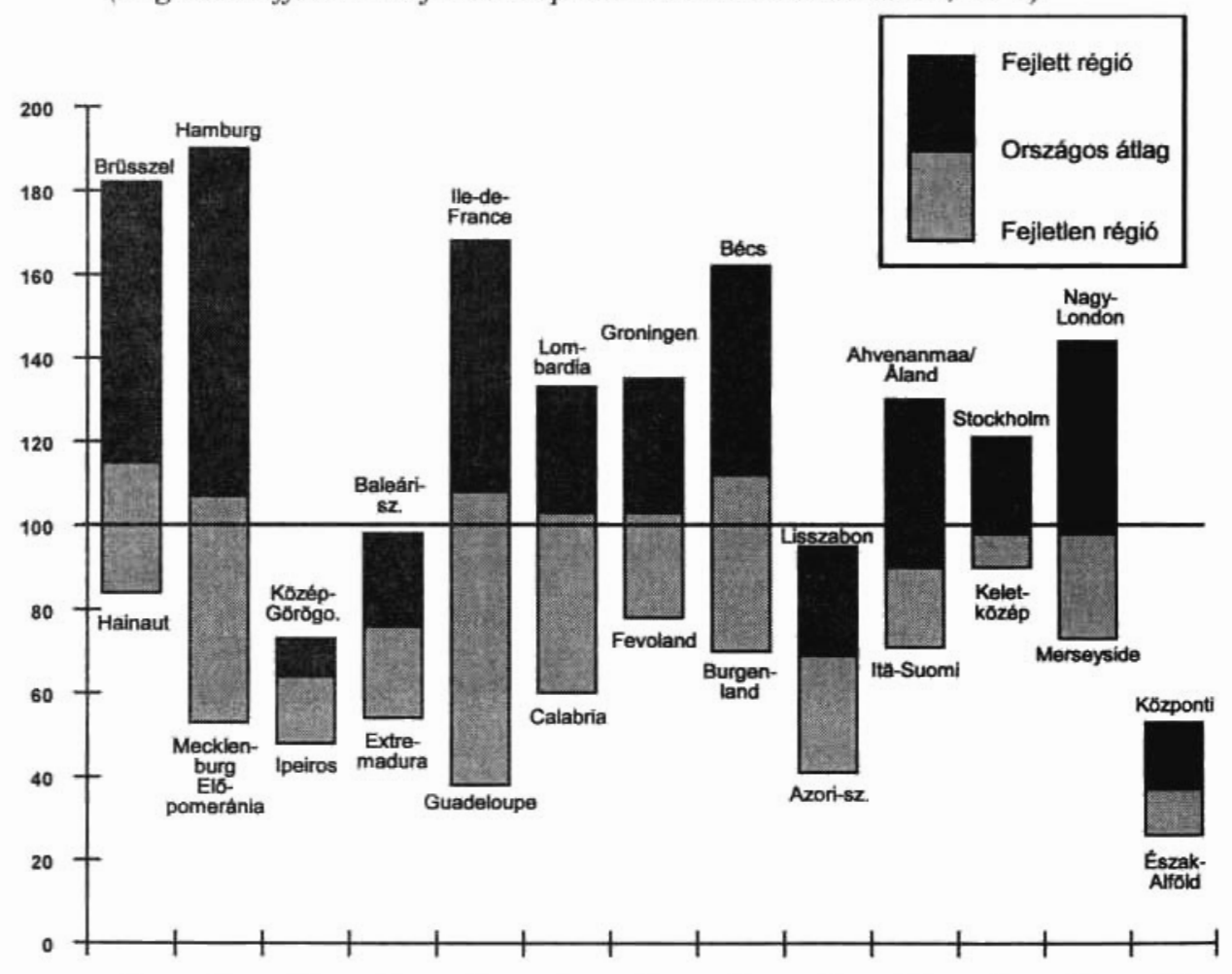

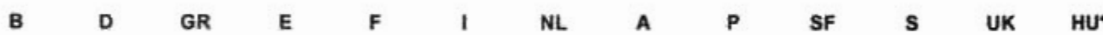

Forrás: First Report on Economic and Social Cohesion. p. 24.; KSH Gyorstájékoztató, 1997. április, május adatai alapján Horváth Gy. szerkesztése. (Megjegyzés: Magyarország: 1995. évi adat) 
A régiók teljesítöképességének alakulását elsősorban az ágazati szerkezet befolyásolja. A föleg a négy kohéziós országban (Írország, Portugália, Spanyolország, Görögország) és a Finnországban található agrárrégiók GDPmutatói vannak jelentösen az EU-átlag alatt, ezekben a jövedelmek növekedési üteme is alacsonyabb. Az ipari régiók - Németországban, Észak-Spanyolországban, Észak-Franciaországban, Észak-Olaszországban, Közép-Angliában és Ausztriában teljesitőképessége meghaladja az Unió átlagait, növekedési rátái azonban csak mérsékelt előnyt jeleznek. Az erös tercier gazdasággal rendelkezö térségek Lisszabon kivételével valamennyi fövárosi régió, észak német, holland és belga területek - GDP-mutatói a legmagasabbak, a növekedési ütem átlagos.

A gazdasági tevékenység túlzott mértékben koncentrálódik a magasan urbanizálódott térségekben. Az $500 \mathrm{fö} / \mathrm{km}^{2}$ feletti népsürüségü régiók az EU összterületének csupán 4\%-át, az össznépességnek viszont $50 \%$-át adják. E területek fajlagos GDP-je a közösségi átlagot 14\%-kal meghaladja. A nagyvárosok dinamikus növekedése a kohéziós országok többségében tovább mélyítette a területi jövedelmi különbségeket.

A regionális egyenlötlenségek másik megnyilvánulási formájában, a munkanélküliségi rátában mind a tagállamok, mind pedig a régiók között markáns különbségek mutathatók ki. Az 1983-1995 közötti idöszakban az Európai Unióban a munkanélküliségi ráta 8,7\%-ról 10,7\%-ra emelkedett. 1983-ban a 25 legmagasabb rátájú régió ( 12 spanyol, 8 brit, 3 belga, 1 olasz régió és Írország egésze) mutatója 17,2\%, 1995-ben (14 spanyol, 6 olasz, 4 finn és I német régió) pedig $22,4 \%$ volt. A legalacsonyabb és legmagasabb rátájú 25 régió különbsége az 1983. évi 3,6-szeresröl 1995-re 4,9-szeresre emelkedett.

A területi egyenlötlenségek alakulásában - gazdaságszerkezeti okokon kivül termelékenységi és foglalkoztatási tényezők játszanak szerepet. Minél magasabb egy régió termelékenységi szinvonala (az egy foglalkoztatottra jutó GDP) és foglalkoztatottsági rátája, annál kedvezőbb az egy lakosra jutó GDP értéke. A két tényező hatása azonban a tagállamokban eltérö módon érvényesül. A duális gazdaságú Németországban és Olaszországban a két komponens és azok kombinációja regionálisan nagy szélsőségeket mutat. A kohéziós országok is különbözőek. Spanyolországban és Írországban a termelékenység az EU-átlaghoz közelít, a foglalkoztatotti ráta azonban alacsony, Görögországban ćs Portugáliában az alacsony munkanélküliségi mutatók gyenge termelékenységgel párosulnak.

A termelékenységi különbségek mérséklését az Unió egyes részein lényegesen eltérő termelési feltételek közepette kell megvalósitani. A gazdagabb régiókban szinte ősszehasonlíthatatlanul kedvezőbbek a modern távközlési adottságok, képzettebb és mủveltebb a munkaerö, kiépült a kutatási-fejlesztési infrastruktúra. Érzékelhető kủlönbségek tapasztalhatók az út- és vasúthálózatban, a déli perifériák autópálya-sürüsége nem éri el az EU-átlag 50\%-át.

\section{Változások 2000 után}

A harmadik reformcsomag föbb alapelveit az EU Bizottságának 1997-ben készült "Agenda 2000" c. dokumentuma körvonalazza. A 2000 után érvényesítendö kohéziós politika célja változatlan marad. A keleti bővítés azonban jelentősen megnőveli a tagállamok közötti és az országokon belüli különbségeket, ezért a 
strukturális és kohéziós támogatások összegét növelni, a felhasználás koncentrációját fokozni célszerü. A 2000-2006 közötti idöszakra tervezett 275 milliárd ECU (1997. évi árakon) kohéziós jellegü kiadások az EU költségvetésének 38,0\%-át adják majd. A strukturális intézkedések egyszerüsítése, a hatékonyság nővelése érdekében a kedvezményezett térségek típusainak számát mérsékelni kívánja az Európai Unió. A ma érvényes 7 kedvezményezett térségformát háromra kell csőkkenteni. Az elmaradott térségek kategóriája megmarad, lehatárolásának szempontjai sem változnak. Az új, 2. célcsoportba azok a térségek kerülnek, amelyek gazdasága szerkezeti problémák miatt hanyatlik, illetve ide sorolandók a depresszió sújtotta városi térségek. Az új, 3. célcsoportba pedig az elöző két kategóriába be nem került, de a munkaerö minősége miatt problematikus térségek kerülnek, ahol az oktatás, a képzés és a szakképzés fejlesztését külön eszkőzökkel kell támogatni. A kedvezményezett térségek számát szükíteni kivánják, a besorolási kritériumok szigorú betartása esetén a támogatott területeken élő népesség aránya 2006-ban 35-40\% lehet (ennek kétharmada él majd elmaradott térségekben).

$\mathrm{Az}$ új elképzelések szerint a Kohéziós Alap jelenlegi formájában és volumenében fennmaradna, továbbra is a transzeurópai közlekedési hálózatok fejlesztését és környezetvédelmi programokat támogatna. A jelenleg érvényes 13 Közösségi Kezdeményezés (amely kb. 400 programot támogat párhuzamosan a strukturális müveletekkel) száma csökkenne, csak három tevékenységi körre (a határmenti együttmüködések fejlesztésére és tervezésére, vidékfejlesztésre és az esélyegyenlőséget növelő humán eröforrás fejlesztésre) terjedne ki.

A gazdasági és a szociális különbségek mérséklésében a támogatási források és a megalapozott regionális fejlesztési programok mellett az Unió a jövőben nagy jelentőséget tulajdonít a decentralizált partneri kapcsolatok fejlesztésének. A tovább egyszerüsitendő döntési mechanizmusban a fejlesztés szereplöi közőtt egyértelmü munkamegosztást kell kialakítani, a döntéseket eröteljesen decentralizálni kell.

\section{A kelet-európai bővités}

\section{A bövités teljesítménycsökkentõ hatása}

A keleti bővités hatásai - a népességszámot és a gazdasági elmaradottságot tekintve - még a mediterrán szárny csatlakozásánál is komolyabb nehézségek elé állítják a Közösséget. Az első szakaszban várhatóan taggá váló Csehország, Lengyelország, Magyarország, Észtország és Szlovénia 63 millió fös népessége 40\%-kal növelné az elmaradott térségek népességszámát, ami azt jelenti, hogy az 1. támogatási célcsoportba besorolt régiókban élő népesség aránya a mai $25 \%$-ról $36 \%$-ra emelkedne. Nem is szólva arról, hogy a kelet-közép-európai régiók fejlettségi mutatói lényegesen rosszabbak, mint a nyugat-európai elmaradott térségeké: egyetlen régió GDP-je sem haladja meg az EU-átlag 75\%-át. A kelet-európai társult tagországok majdani csatlakozása egyébként jelentősen mérsékli az Unió teljesitőképességét. Az alapitás óta bekövetkezett és a tervezett bővités az egy före jutó GDP-t 30\%-kal mérsékelte, eredeti önmagához képest az új évezred kőzössége az elmaradottságot jelentő 75\%-os GDP-határon áll majd (1. táblázat). 


\section{TÁBLÁZAT}

Az egymást követö bövítések nyomán változó EU-alapadatok

(Changes in basic indeces of the EU as result of subsequent enlargements)

\begin{tabular}{|l|c|c|c|c|c|}
\hline \multicolumn{1}{|c|}{ Bővítés } & $\begin{array}{c}\text { Terület- } \\
\text { növekedés } \\
\%\end{array}$ & $\begin{array}{c}\text { Népesség- } \\
\text { növekedés } \\
\%\end{array}$ & $\begin{array}{c}\text { GDP } \\
\text { növekedés } \\
\%\end{array}$ & $\begin{array}{c}\text { Az egy före } \\
\text { jutó GDP } \\
\text { változása \% }\end{array}$ & $\begin{array}{c}\text { Változás } \\
\text { EUR6=100 }\end{array}$ \\
\hline EUR 6 $\rightarrow$ EUR 9 & 31 & 32 & 29 & -3 & 97 \\
\hline EUR 9 $\rightarrow$ EUR 12 & 48 & 22 & 15 & -6 & 91 \\
\hline EUR 12 $\rightarrow$ EUR 15* & 43 & 11 & 8 & -3 & 89 \\
\hline EUR 15 $\rightarrow$ EUR 26 & 34 & 29 & 9 & -16 & 75 \\
\hline
\end{tabular}

Megjegyzés: * A keletnémet tartományokkal egyưtt.

Forrás: Agenda 2000. p. 110.

Az Európai Unió reformcsomagja számol a társult keleti országok támogatásával. 2000-2006 között a strukturális kiadások egyhatod részét kívánják az új tagállamoknak folyósítani, a programidőszak végén támogatásuk a kiadások $30 \%$-át éri majd el. Lévén, hogy az új tagállamok az elmaradott térségi célcsoportba tartoznak majd, és többségük viszonylag kis méretü, az Unió nem tervezi az országokon belüli megkülönböztetett támogatási térségek kialakítását a közösségi finanszírozás céljaira. A belső különbségek mérséklésének feladatait a tagország általános teljesítőképességének a javításával kívánja megoldani. Az országok többségében tapasztalható jelentős és növekvö területi különbségeket a nemzeti kormányoknak kell mérsékelniük saját intézményrendszerükön keresztül. Az EU strukturális támogatásait a kormányok által kidolgozott, a regionális, az ágazati szervekkel és a szociális partnerekkel egyeztetett nemzeti területfejlesztési programok alapján folyósítja.

A Strukturális Alapokhoz való majdani hozzáférést azonban jelenleg - az EU Bizottságának értékelése szerint - több tényező akadályozza:

- egyáltalán nincsenek vagy nagyon gyengék a regionális politikai eszközök;

- fejletlen az intézményrendszer, erötlen az ágazatközi koordináció a regionális fejlesztési programok társfinanszírozásában, a területi önkormányzatoknak nincsenek eszközeik, hiányos a szakértelmük;

- a költségvetési szféra is gyökeres átalakitásra szorul: mennyiségi szempontból ma még nehezen mobilizálhatók az állami pénzalapok a strukturális támogatások kiegészitésére, tisztázatlan a társfinanszírozáshoz szükséges források mennyisége, minöségi szempontból megoldatlan a felhasználás hatékonyságának garantálása, hiányzik az EU-konform monitoring.

\section{A társult tagállamok területi szerkezete}

A tervgazdaságban folytatott látszólagos kiegyenlítő politika szinte egyetlen eredménye az volt, hogy a nagyrégiók kőzött az európai helyzetképtől eltérö, kiugró különbségek nem regisztrálhatók. Az általánosan gyenge gazdasági teljesítőképesség miatt az elmaradottság területi eloszlása egyenletesnek tünik. 
E megállapításunk a nagy területi egységekre vonatkozóan igaz, a kisebb térségek teljesítőképességében - mint Európa más országaiban - a különbségek sokkal nagyobbak. Az egy före jutó GDP alapján Kelet-Európában a regionális különbségek mértéke nem tér el lényegesen az Európai Unió adataitól (2. táblázat).

Az általános elmaradottság bizonyítja, hogy nincs Kelet-Európában az uniós átlagot meghaladó régió, és csupán három fövárosi (a prágai, a budapesti és a szófiai) régió kőzelíti meg az átlag 75\%-át (3. táblázat). A régiók dőntő tőbbsége az európai regionális rangsor legvégén helyezkedik el, csupán néhány cseh, lengyel és magyar régió teljesítöképessége jobb, mint a legelmaradottabb portugál, görög és spanyol régióké.

\section{TÁBLÁZAT}

A legfejlettebb és a legfejletlenebb régió közti különbség az európai országokban az egy före jutó GDP alapján, 1993 (vásárlóerô-paritáson)

(Differences between the most and the least advanced regions in the EU by the value of GDP/capita, 1993)

\begin{tabular}{|c|c|c|c|}
\hline \multirow[t]{2}{*}{ Ország } & Legfejlettebb & Legfejletlenebb & \multirow{2}{*}{$\begin{array}{c}\text { Az egy före jutó } \\
\text { GDP } \\
\text { különbsége }\end{array}$} \\
\hline & \multicolumn{2}{|c|}{ régió } & \\
\hline Németország & Hamburg & Thüringia & 6,48 \\
\hline Bulgária & Szófia & Montana & 5,00 \\
\hline Magyarország* & Budapest & Észak-Alföld & 2,48 \\
\hline Olaszország & Lombardia & Calabria & 2,33 \\
\hline Portugália & Lisszabon & Alentejo & 2,30 \\
\hline Belgium & Brüsszel & Hainaut & 2,12 \\
\hline Lengyelország & Varsó & Varsói régió & 2,11 \\
\hline Spanyolország & Valencia & Extremadura & 1,99 \\
\hline Franciaország & Île-de-France & Languedoc-Roussillon & 1,96 \\
\hline Szlovákia & Ny-Szlovákia & K-Szlovákia & 1,90 \\
\hline Görögország & Közép-Görögország & Észak-Égei régió & 1,66 \\
\hline Csehország & Prága & Dél-Morvaország & 1,61 \\
\hline Egyesült Királyság & Délkeleti régió & Észak-Írország & 1,58 \\
\hline Hollandia & Groningen & Friesland & 1,52 \\
\hline Dánia & Fövárosi & Kelet-Dánia & 1,41 \\
\hline Románia & Bukarest & Dél-Moldova & 1,37 \\
\hline
\end{tabular}

1995

Forrás: Eurostat, Brüssels, 1994; The Impact on Cohesion of EU Enlargement alapján Horváth Gy. számításai. 


\section{TÁBLÁZAT}

A kelet-közép-európai régiók megoszlása fejlettségi kategóriák szerint, 1993 (Distribution East Central European regions by GDP-capita categories)

\begin{tabular}{|l|c|c|c|c|c|c|c|}
\hline \multirow{3}{*}{ Ország } & \multicolumn{6}{|c|}{ Az egy före jutó GDP az Európai Unió átlagának } & \multirow{2}{*}{ Összesen } \\
\cline { 2 - 7 } & $-20,0$ & $\begin{array}{c}20,1- \\
30,0\end{array}$ & $\begin{array}{c}30,1- \\
40,0\end{array}$ & $\begin{array}{c}40,1- \\
50,0\end{array}$ & $\begin{array}{c}50,1- \\
60,0\end{array}$ & $\begin{array}{c}60,1- \\
75,0\end{array}$ & \\
\hline Bulgária & 6 & 2 & - & - & - & 1 & 9 \\
\hline Csehország & - & - & - & - & 6 & 1 & 7 \\
\hline Lengyelország & 1 & 8 & - & 1 & - & - & 10 \\
\hline Magyarország* & - & 2 & 2 & 1 & - & 1 & 6 \\
\hline Románia & 2 & 7 & - & - & - & - & 9 \\
\hline Szlovákia & - & - & 3 & - & - & - & 3 \\
\hline Összesen & 9 & 19 & 5 & 2 & 6 & 3 & 44 \\
\hline
\end{tabular}

Forrás: The Impact on Cohesion of the EU Enlargement. Különböző oldalak alapján összeállította: Horváth Gy. (Megjegyzés: • 1995.)

Ugyan valamennyi országban a fôvárosi régiók GDP mutatója a legmagasabb (az országos átlagot 100-nak véve a fövárosi adatok a következők: Prága: 153, Varsó: 170, Budapest: 181, Bukarest: 125, Szófia: 250, Pozsony: 175), a hazai őssztermékből való részesedés koncentrációja nem nagyobb, mint a nyugat-európai országokban.

A változások regionális hatásait vizsgálva ugyanis azt érzékelhetjük, hogy a fővárosi régiók minden országban az átalakulás nyertesei lettek, míg a többi térségnek a korábbi szocialista rendszerben elfoglalt pozíciója megváltozott, az átalakulás különböző pályákon zajlik (4. táblázat).

\section{TÁBLÁZAT}

A rendszerváltozás hatása a régiók helyzetére (Impact of transition process on the position of distinct types of regions)

\begin{tabular}{|c|c|c|c|}
\hline & & \multicolumn{2}{|c|}{ Az átalakulás hatása } \\
\hline & & Kedvező & Kedvezőtlen \\
\hline \multirow{2}{*}{$\begin{array}{l}\text { A tervgazdaságban } \\
\text { elfoglalt pozíció }\end{array}$} & Jó & $\begin{array}{l}\text { Pozitív folyamatosság } \\
\text { (Multifunkcionális } \\
\text { nagyvárosok) }\end{array}$ & $\begin{array}{l}\text { Negatív megszakitottság } \\
\text { (Nehézipari központok) }\end{array}$ \\
\hline & Rossz & $\begin{array}{l}\text { Pozitiv megszakitottság } \\
\text { (Nyugati határmenti } \\
\text { régiók) }\end{array}$ & $\begin{array}{l}\text { Negatív folyamatosság } \\
\text { (Elmaradott agrártér- } \\
\text { ségek) }\end{array}$ \\
\hline
\end{tabular}


Bár a szerkezet átalakítás a hagyományos fejlödési pólusokat is hátrányosan érintette, a korábban diverzifikált gazdasággal és viszonylag összetettebb társadalmi-gazdasági funkciókkal rendelkezó nagyvárosi régiók csekélyebb veszteséggel juthatnak az átalakulási folyamat végére, mint a monokultúrás iparvidékek és a rurális térségek. A piacosodás térnyerése és a modern gazdasági szerkezet kialakulása érzékelhető Varsó, Krakkó, Poznan, Wroclaw vajdaságokban Lengyelországban, a budapesti agglomerációban, az észak-dunántúli régióban Magyarországon, Prága, Karlovy Vary és Pozsony környékén. Ezekben a régiókban az országos átlagot jelentősen meghaladja a magánvállalkozások száma, a külfơldi tőke részaránya, a szolgáltató szektor (különösen az üzleti- és a pénzügyi szolgáltatások növekedése nyomán) lassan a gazdaság domináns ágazatává válik. Ezek a térségek a fontosabb innovációk hordozói, új termékek kibocsátói, a nemzetközi gazdasági együttmüködések szereplöi.

A szerkezeti átalakulás egyértelmű vesztesei viszont a munkásosztály korábban erösen preferált fellegvárai. A kitermelö-, nehéz- és könnyüipari központok és agglomerációik a depresszió tipikus jegyeit mutatják: magas a munkanélküliség, a csődbe jutott vállalatok aránya, nehéz a munkaerő szakképzettségét konvertálni, gyenge a vállalkozói szellem, a progresszív munkaerő elvándorol, a környezet erősen károsodott. Lengyelországban a legnagyobb transzformációs veszély FelsőSziléziát fenyegeti. A szénbányászat, a nehéz- és vegyipar mély válságba került. A négymilliós térség aktív keresőinek közel fele, 800 ezer fö dolgozik a depresszió sújtotta ágazatokban. Méreteiben kisebb, de hasonló következményekkel járó problémákkal küszködik az észak-morva és a nyugat-cseh régió Csehországban, Plovdiv, Várna és Rusze térsége Bulgáriában, a román Vajdahunyad és Braila, a szlovák Kassa városok és környékük, a borsodi és a nógrádi iparvidék Magyarországon. Ma még nem lehet egyértelmüen megrajzolni a nagyipari központok jövőjét. Vannak olyan térségek (pl. Felsö-Szilézia katowicei vajdasága), amelyek könnyen adaptálták a piacgazdaság új elemeit, a hanyatló ágazatok termeléskiesését privatizáció és külföldi tőkebevonás révén részben pótolni tudták, viszonylag kedvező a demográfiai szerkezetük, jó az infrastruktúrájuk, kiépült kutatási-fejlesztési hálózatuk van. A monokultúrás vállalatvárosok jövője azonban teljesen bizonytalan, sorsuk megpecsételődni látszik.

Az átalakulás a korábban elmaradott térségek helyzetét még kilátástalanabbá tette. A rurális területek mezőgazdasági vállalatai szétzilálódtak, a keleti piacokra termelő élelmiszeripar kibocsátása a tizedére csökkent. A fejletlen infrastruktúra, a népesség kedvezőtlen korösszetétele és alacsony képzettsége miatt e területek tovább erodálódnak.

Az átmenet regionális következményei Kelet-Európában a népesség jóval nagyobb hányadát érintették kedvezőtlenül, mint a szerkezetátalakulás két-három évtizeddel korábbi hatásai Nyugat-Európa népességét (5. táblázat). A változásokra sem a kormányok, sem a területi szereplök nem voltak felkészülve. A területfejlesztési politika jelentős késéssel - a 90-es évtized közepén - és tőbbnyire az Európai Unió fejlesztési támogatása igénybevételének feltételeként keltette fel a kelet-európai gazdaságpolitikusok figyelmét. 


\section{TÁBLÁZAT}

A különbözõ fejlettségũ régiókban élö népesség becsült adatai Kelet-Közép-Európában, 1995

(Estimated size of population in distinct types of regions in East Central Europe, 1995)

\begin{tabular}{|l|c|c|c|c|c|c|c|c|}
\hline \multirow{3}{*}{ Ország } & \multicolumn{2}{|c|}{ Elmaradott } & \multicolumn{2}{c|}{ Depressziós } & \multicolumn{2}{c|}{ Fejlödő } & \multicolumn{2}{c|}{ Fejlett } \\
\cline { 2 - 10 } & $\begin{array}{c}\text { Millió } \\
\text { fö }\end{array}$ & $\%$ & $\begin{array}{c}\text { Millió } \\
\text { fö }\end{array}$ & $\%$ & $\begin{array}{c}\text { Millió } \\
\text { fö }\end{array}$ & $\%$ & $\begin{array}{c}\text { Millió } \\
\text { fó }\end{array}$ & $\%$ \\
\hline Bulgária & 2,68 & 34,0 & 1,07 & 12,7 & 2,44 & 29,0 & 2,05 & 24,3 \\
\hline Csehország & 2,81 & 27,3 & 1,55 & 15,0 & 2,73 & 26,6 & 3,20 & 31,1 \\
\hline Lengyelország & 13,78 & 36,4 & 8,30 & 21,9 & 8,36 & 22,0 & 7,46 & 19,7 \\
\hline Magyarország & 3,41 & 34,0 & 0,44 & 4,4 & 2,95 & 29,0 & 3,33 & 32,6 \\
\hline Románia & 12,21 & 53,6 & 1,87 & 8,2 & 2,98 & 13,1 & 5,69 & 25,1 \\
\hline Szlovákia & 1,89 & 35,8 & 1,06 & 20,1 & 1,07 & 20,3 & 1,25 & 23,8 \\
\hline
\end{tabular}

Forrás: A szerző becslése nemzeti területfejlesztési forrásmunkák alapján. Az elmaradott, a fejlődő és a fejlett térségek adatait a kőzépszintū területi egységek alapján számítottuk ki.

\section{A regionális politika gyenge pozíciója}

Amikor a 80-as évtized végén érzékelhetők voltak a tervgazdaság összeomlásának első jelei, a makroszabályozás átalakításának prioritásai között szinte egyetlen országban sem jelent még meg a regionális politika eszközrendszere kialakitásának az igénye. Ha voltak is próbálkozások regionális ösztönzők bevezetésére, a javaslatok az ágazati minisztériumok érdekellentétei miatt hamar lekerültek a napirendröl. A helyi-területi önkormányzati rendszer erejét saját szervezeti formáinak a kialakítása és finanszírozási bázisának a megteremtése kötötte le, a szükös állami eröforrások sem kedveztek annak, hogy az újraelosztás rendszere egy újabb elemmel, a területfejlesztési támogatással bővüljön.

A regionális politika kialakulását tehát három tényező akadályozta az átmenet időszakában: az önálló regionális politika megjelenésének korlátozott támogatottsága kormányzati körökben, a területi fejlesztési intézményrendszer gyengesége és a területi közigazgatás megoldatlansága. Elvétve készültek ugyan koncepciók és fejlesztési tervek, ezek azonban ad hoc jellegüek voltak, módszertani megalapozottságuk gyenge volt, alkalmi célok megoldását kívánták elösegiteni jól körulhatárolt szervezeti rendszer és eszközök nélkül. Magyarország volt az egyetlen, amely legalább a központi kormányzati struktúrában megjelenitette a területfejlesztést, mint államilag támogatott tevékenységet. Az 1990-1994 közötti időszak terulletfejlesztése azonban nem lépte túl az eseti beavatkozások politikáját, az újjászervezett területfejlesztési alap csekély volumene, az elkülönült, szétaprózott finanszírozás miatt a ráfordítások gyenge hatást fejtettek ki. Csehország a kisvállalkozások támogatásában próbálkozott regionális kedvezmények alkalmazásával, és Szlovénia készített területfejlesztési támogatási programot az instabil népességû térségek revitalizálására. Több országban az ágazati minisztériumok a regionális hanyatlás tüneti kezelésére eszközeik elosztásában 
alkalmaztak területi szempontokat, ezek azonban nem nevezhetők struktúrapolitikai intézkedéseknek.

Látnunk kell azt is, hogy a kelet-európai országok politikai döntéshozóinak több dilemmával kell szembenézniük, ezek értelemszerüen nehezitik a konzisztens regionális politika kialakulását. Az első, mindeddig válasz nélkül maradt kérdés, hogy a regionális politika egyáltalán hatékony eszkőz-e az átmenet feladatainak a megoldásában. Mivel a válság az egyes nemzetgazdaságok valamennyi térbeli pontján érezteti a hatását, nem lehet-e a szükös eröforrások idöszakában, például a korszerủ iparpolitikával kedvezőbb változásokat elérni, mint a redisztribúción alapuló regionális politikával.

A másik általános hiányosság, hogy az országok döntö többségében a regionális politika jogi keretei, alkotmányos alapjai hiányoznak. Nincsenek sem központi, sem pedig a szubnacionális intézmények a fejlesztés tervezésének és végrehajtásának szervezésére, a kőzősségi és a magánszektor együttmüködésének az ösztönzésére. A még mindig erősen centralizált fejlesztési források között nincs megfelelő koordináció, az ágazati érdekek harmonizálására néhány helyen létrehozott központi intézmény müködése formális. A minisztériumok és az ágazati politikusok között éles verseny tapasztalható a fejlesztési politika és forrásai feletti rendelkezési jogokért. Hasonló jelenségek figyelhetớk meg az államigazgatás alsóbb szintjein is. A regionális fejlesztési jellegü feladatokat rendszerint a központi minisztériumok dekoncentrált szerveihez telepítik, mint ahogy a külföldi támogatással létrehozott fejlesztési ügynőkségek is centrális alárendeltségben müködnek.

S végül, a regionális fejlesztési politikát befolyásoló harmadik tényezö - amelyet már kedvező hatásnak tekinthetünk - az Európai Unióhoz való csatlakozás kővetelményeiből fakad. A potenciális tagjelölteknek ugyanis politikájukat és intézményrendszerüket fokozatosan hozzá kell igazítaniuk az integrációs szabályokhoz, kiváltképpen a strukturális és a kohéziós programoknak való megfeleltség érdekében. Az európai módszerek elsajátítását azonban akadályozza, hogy mind a Phare támogatások, mind pedig a bilaterális finanszírozású programok irányitása kizárólag a központi minisztériumok kezében van, felhasználásuk nem tervszerü, nem illeszkedik országos fejlesztési koncepcióba, a regionális aktorok csupán egyszerü recipiensei és nem aktív formálói e programoknak.

\section{Az új tagok támogatása}

A Strukturális Alapok átalakítását általában szükségszerünek tekintik, de annak érdemi módozatairól folytatandó vita valójában még csak most kezdődött. Ezért a továbbiakban, számos feltételezéssel, absztrakcióval kell élnünk:

- Az első feltételezés az, hogy az első lépcsőben a CEFTA országok csatlakozásával - mégpedig egyidejü csatlakozásával - számoltunk, azaz Csehország, Lengyelország, Magyarország, Szlovákia és Szlovénia belépését feltételeztük, a többi társult ország belépésének hatásait nem kalkuláltuk. Nem számoltunk kưlön Ciprus és Málta belépésével sem, de tekintve, hogy a két ország egyutttes lakossága sem éri el az 1 milliót, ennek közősségi hatása nem számottevő. Nem jelent számottevő változást Szlovákia kimaradása sem, hiszen népessége az így kibővült Unió lakosságának 1,2\%-át tenné ki. 
Természetesen jóval nagyobb - sok tekintetben meghatározó - hatása van Lengyelország belépésének vagy kívül maradásának;

- Feltételeztük, hogy az eddig támogatott EU régiók továbbra is támogatásban részesülnek, csak a támogatott régiók köre kibővūlne az újonnan csatlakozott országokkal. A kisebb ellenállás irányában haladva, tehát nem a támogatottak köre, hanem az egy-egy régiónak jutó támogatás szintje változna a külōnbőzõ alternatívák függvényében;

- Végül feltételeztük, hogy a pénzeszkőzök forrásszabályozása, továbbá a felosztás szabályai, módszerei alapvetően megegyeznek az 1994-99-es hatéves költségvetési tervezési periódus elveivel.

A támogatás alapkritériuma az, hogy az adott NUTS 2 régió egy före jutó hazai összterméke kevesebb, mint 75\%-a legyen az Unió átlagának. Ezt a szabályt azonban valójában ma sem értelmezik mereven. Az 1995. évi bővités elötti EU 181 régiója kőzull 54 részesült az 1. cél alapján támogatásban, és ebböl 12 fejlettségi szintje már 1990-ben meghaladta az EU átlagának 75\%-át.

Az öt CEFTA-ország fejlettsége - vásárlóerö-paritáson - ma összességében az EU-átlag 32\%-át teszi ki, csatlakozásuk az EU-átlag 10,4 százalékos csőkkenését okozná. A szabályok következetes alkalmazása esetén a támogatástól elesnének mindazok a régiók, amelyek a mai uniós átlag $67 \%$-a felett vannak. Ez a meglévő, már $75 \%$ feletti 12 EU régió mellett további kilencet diszkvalifikálna az 1 . céi alapján támogatásra.

Az Európai Unió jelenlegi lakosságának 25\%-a, 92,2 millió fó él elmaradottnak minôsitett és az 1. cél alapján támogatott terūleten. Ha a kritériumot szigorúan értelmeznék, a 92,2 millió fô 77,9 millióra csőkken. Dánia, Finnország és Svédország kivételével minden tagországban van az 1 . célcsoportban támogatott terullet. Görögország, Portugália és Írország 100\%-ban az, de Spanyolország közel $60 \%$-a, Olaszország 36,6\%-a és Németország 20,7\%-a is e kategóriába tartozik.

A CEFTA-országok felvétele esetén egész területūk az 1 . cél alapján támogatottnak minősül. Ha az új körülmények között a 75\%-os határt mereven értelmeznénk, akkor a jelenlegi Unió 92,2 millió 1 . cél alapján támogatott népességéből csak 52,6 millió maradna, és az 1. cél alapján támogatott népességnek 56\%-a, az új, CEFTA-ból felvett tagországok területére kerülne. Ez olyan mértékü eltolódás, amely az érintett országok tőbbsége számára elfogadhatatlan. Ugyanakkor az is igaz, hogy az e cél alapján támogatott népesség aránya $25 \%$-ról csak 27,6\%-ra nöne.

Az Objective 1. teljes elöirányzatának 38,9\%-a Lengyelországnak járna, és a teljes osszeg 57,4\%-át az öt CEFTA-országban kell felhasználni. Magyarországon az 1. cél által támogatott teruletek lakosságának 6,6\%-a élne és GDP szintje, valamint munkanélkualiségi rátája alapján a támogatások 7,8\%-át lenne indokolt itt felhasználni.

Érdemes összevetni, hogy mennyi lenne a jelenlegi 1. cél által támogatott EU tagországok részesedésének csőkkenése e változás nyomán (ősszevetve az 1994-99. évi tényleges arányokkal) (6. táblázat). 


\section{TÁBLÁZAT}

Az EU-tagországok elmaradott térségei támogatásának

csökkenése a keleti bővités után

(Prospective decrease of financial support of backwarded regions in the EU after the eastern enlargement)

\begin{tabular}{|l|c|c|c|}
\hline \multicolumn{1}{|c|}{ Ország } & $\begin{array}{r}1994-99 \text { tény, } \\
\%\end{array}$ & $\begin{array}{c}\text { Keleti bövítés után } \\
\text { számított, \% }\end{array}$ & Csökkenés \\
\hline Ausztria & 0,2 & 0,1 & $-0,1$ \\
\hline Belgium & 0,8 & 0,5 & $-0,3$ \\
\hline Franciaország & 2,3 & 1,1 & $-1,2$ \\
\hline Görögország & 14,8 & 4,6 & $-10,2$ \\
\hline Hollandia & 0,1 & 0,05 & $-0,05$ \\
\hline Írország & 6,0 & 1,5 & $-4,5$ \\
\hline Nagy Britannia & 2,5 & 1,4 & $-1,1$ \\
\hline Németország & 14,5 & 9,3 & $-5,2$ \\
\hline Olaszország & 15,8 & 8,7 & $-7,1$ \\
\hline Portugália & 14,9 & 3,8 & $-11,1$ \\
\hline Spanyolország & 28,0 & 11,8 & $-36,2$ \\
\hline
\end{tabular}

Forrás: Horváth Gy,-Illés I. 1997. p. 102.

Kétségtelenül legnagyobbak Spanyolország, Portugália, Írország és Görögország, az eddigi fö kedvezményezettek viszonylagos veszteségei. Összességében a legtöbbet Spanyolország, arányaiban Portugália és Írország veszít. Megjegyzendő, hogy az utóbbi két veszteség nemcsak a keleti bővités következménye, hanem azé is, hogy maga az EU is következetlen volt módszerei alkalmazásában: Írország és Portugália többet kapott, mint amennyi objektív számítás alapján járt volna nekik, és némileg hasonló a helyzet Olaszország arányvesztésével. A többi országban pedig a korábbi arány sem volt jelentékeny, a veszteség ezért sem igazán fájdalmas, nem beszélve arról, hogy ezek az országok nem elsősorban az 1. cél alapján jutnak támogatáshoz. Spanyolország vezetỏ helyét az ugyanolyan népességszámú, de jóval alacsonyabb GDP-vel rendelkező Lengyelország foglalná el a támogatások tekintetében.

Az abszolút ősszegekre vonatkozó számításunkat az 1999. évre végeztük el. Jóllehet tisztában vagyunk vele, hogy 1999-ben a csatlakozás még nem következik be, mégis több érv szól ezen év választása mellett.

- 1999-re az EU Strukturális Alapjairól részletes számítások állnak rendelkezésre, és a változásokkal összevetve következtetések levonását teszik lehetővé;

- 1999. az utolsó év, amelyre nézve az Európai Unió a Strukturális Alapokból kötelezettségeket vállalt. Valószinü, hogy minden további vitánál és érdekegyeztetésnél az ez évi arányok fogják a kiinduló pontot jelenteni.

Miközben a befizetési kötelezettség mindenki számára nőne, beleértve az új tagállamokat is, az is világos, hogy a bővítés terhe így elsősorban és döntően a gazdag, elmaradott területekkel nem rendelkezö tagállamokat érintené, hiszen a 
befizetett többletösszegböl ők vajmi keveset, vagy semmit nem kapnának vissza. A CEFTA-országok fejlettségi, illetve elmaradottsági szintje pedig olyan, hogy a jelenlegi módszerek alkalmazásának folytatásával soha nem látott és remélt támogatásban részesülnének (7. táblázat).

\section{TÁBLÁZAT}

1999. évi részesedés a Strukturális és Kohéziós Alapokból

(Share of distinct states of Cohesion Funds in 1999)

\begin{tabular}{|l|c|c|c|c|c|}
\hline \multicolumn{1}{|c|}{ Ország } & $\begin{array}{c}\text { Azz l. cél } \\
\text { elöirányzata }\end{array}$ & $\begin{array}{c}\text { A többi } \\
\text { cél } \\
\text { elöirányzata }\end{array}$ & $\begin{array}{c}\text { Közösségi } \\
\text { kezdeménye- } \\
\text { zések }\end{array}$ & $\begin{array}{c}\text { Kohéziós } \\
\text { Alap }\end{array}$ & Összesen \\
\hline Ausztria & 127 & 202 & 21 & - & 350 \\
\hline Belgium & 126 & 101 & 44 & - & 271 \\
\hline Dánia & - & 76 & 16 & - & 92 \\
\hline Finnország & - & 239 & 23 & - & 262 \\
\hline Franciaország & 291 & 1032 & 242 & - & 1565 \\
\hline Görögország & 1258 & - & 174 & 265 & 1697 \\
\hline Hollandia & 14 & 191 & 64 & - & 269 \\
\hline Irország & 409 & - & 73 & 109 & 591 \\
\hline Luxemburg & - & 9 & 3 & - & 12 \\
\hline Nagy Britannia & 377 & 766 & 238 & - & 1381 \\
\hline Németország & 2550 & 570 & 332 & - & 3452 \\
\hline Olaszország & 2393 & 464 & 286 & - & 3143 \\
\hline Portugália & 1030 & - & 160 & 217 & 1407 \\
\hline Spanyolország & 3228 & 461 & 412 & 956 & 5057 \\
\hline Svédország & - & 160 & 19 & - & 179 \\
\hline Csehország & 1439 & - & 164 & 234 & 1837 \\
\hline Lengyelország & 10680 & - & 666 & 1143 & 12489 \\
\hline Magyarország & 2143 & - & 164 & 279 & 2586 \\
\hline Szlovákia & 1193 & - & 92 & 149 & 1434 \\
\hline Szlovénia & 304 & - & 36 & 47 & 387 \\
\hline Összesen & 27480 & 4271 & 3227 & 3400 & 38378 \\
\hline
\end{tabular}

Forrás: Illés I. 1997. p. 32.

- Az 1999. évi eredeti elöirányzat nem meríti ki az Európai Tanács által a GDP 1,27\%-ában meghatározott felsỏ értéket sem. Ha figyelembe vesszük, hogy a jelenlegi tagországok évente átlagosan 2,5\%-kal növekednek, hogy az EU idöközben három, viszonylag gazdag országgal (Ausztria, Svédország, Finnország) bővült, továbbá a CEFTA-beli új tagországok GDP-je is a hátralevő időszakban dinamikusan, évi mintegy 4\%-kal nö, akkor az 1999. évi Strukturális és Kohéziós Alapok összege az eredetileg elöirányzott 30 milliárd ECU helyett legalább 38-39 milliárdra nöhet; 
- Eddig a bővités forrásszülkítő hatásait kizárólag az Objective 1 . céltámogatásaiból részesülö, viszonylag kevésbé fejlett országokra terheltük rá. Ha az egyenlöbb teherelosztás érdekében a 2-6. célok kereteit is mintegy egyharmadával - csökkentjük, és az így felszabaduló forrásokat az 1 . célra, továbbá a Kohéziós Alapra csoportosítjuk át, akkor e források szükössé válása bizonyos fokig enyhíthető.

Ez a variáns nem változtat - nem változtathat - azon a tényen, hogy - ha a hozzájárulás 1,27\%-os plafonja nem léphető át - a keleti bővítés fơ vesztesi Portugália, Írország, Görögország és Spanyolország lesznek. Görögország az 1999re előirányzott 3,4 Mrd ECU helyett 1,7 Mrd-ot, Írország 1,4 Mrd helyett 0,6 Mrd-ot, Portugália 3,4 Mrd helyett 1,4 Mrd-ot kapna. Még egyszer hozzá kell tenni, hogy ez a csökkenés csak részben a keleti bővités következménye, részben az EU saját szabályaié, amelyektöl e támogatások megállapításakor egyszerüen eltekintettek. Portugália és Görögország pl. az EU legalacsonyabb munkanélküliséggel rendelkező tagállamai közé tartozik, Írország pedig egységesen kezelve - már túllépte a 75\%-os küszöböt.

Magyarország 2586 millió ECU támogatásban részesülne. Ez az összeg igen jelentős, de lényegesen alacsonyabb, mint az ugyanolyan területü és lakosságú, de lényegesen kedvezőbb fejlettségi szintü és munkanélküliségü Portugália 1999-re ténylegesen elöirányzott támogatása (8. táblázat).

\section{TÁBLÁZAT}

Portugália és Magyarország elõirányzott, illetve hipotetikus támogatása 1999-re, millió ECU

(Proposed and hypothetical support for Portugal and Hungary in 1999, million ECU)

\begin{tabular}{|l|c|c|}
\hline & $\begin{array}{c}\text { Portugália } \\
\text { (tényleges elöirányzat) }\end{array}$ & $\begin{array}{c}\text { Magyarország } \\
\text { (hipotézis a fejlettség } \\
\text { alapján) }\end{array}$ \\
\hline $\begin{array}{l}\text { Strukturális Alapokból } \\
\text { (országalapok) }\end{array}$ & 2706 & 2143 \\
\hline Közösségi Kezdeményezések & 239 & 164 \\
\hline Kohéziós Alap & 468 & 279 \\
\hline Ósszesen & 3413 & 2586 \\
\hline
\end{tabular}

Forrás: Illés I. 1997. p. 33.

\section{A magyar regionális politika}

A jelenlegi regionális politika erôs és gyenge elemei

A magyar területfejlesztés komplex és magas szintũ jogi szabályozása, speciális intézményrendszere úttörő jellegũ és egyedi Kelet-Közép-Európában, söt sok EU-tagállam számára is mintaértékủ lehet. Az 1996. évi XXI. törvény a területfejlesztésröl és területrendezésröl, céljait tekintve megfelel a társadalmi igazságosság, a méltányosság és a szolidaritás elveinek, az általános kohéziós 
céloknak. Az Országos Területfejlesztési Koncepció szerkezete, regionális fejlesztési orientációja részben kielégíti a nemzeti fejlesztési programdokumentum követelményeit, a hosszú távú fejlesztési célok EU-kompatibilitását.

Az EU kohéziós politikájának fỏ irányát hosszú távra elörevetítö dokumentum, az Agenda 2000 - miközben általában kedvezötlen megállapitásokat fogalmaz meg a kelet-európai csatlakozni szándékozó országok regionális politikai felkészültségérōl - Magyarországot pozitív példaként említi. Az EU Magyarországról készitett jelentése a kővetkezőket emeli ki:

- Csak Magyarországon létezik területfejlesztési törvény;

- E törvény alapelvei harmonizálnak az Unió célkitüzéseivel;

- A törvény végrehajtását kísérő változások nyomán az ország képes lesz az uniós szabályok átvételére, a Strukturális Alapok hatékony felhasználására;

- A végrehajtás során az új intézmények kialakulatlansága gondot okozhat;

- Nem kielégítỏ a minisztériumok, a regionális és a helyi szervek közötti koordináció;

- Nem érzékelhető pontosan, hogy a hazai regionális fejlesztési források miként feleltethetök meg az EU Strukturális Alapjainak pénzügyi eszközeivel, nehezen becsülhető meg Magyarország társfinanszírozási képessége;

- A területfejlesztésre szánt források szükösek;

- Magyarországnak a Strukturális Alapok felhasználásának ellenörzéséhez szulkséges mechanizmusokat ki kell építenie;

- Az államigazgatással szembeni alapkövetelmény: magas szakmai színvonal és megkörnyékezhetetlenség.

\section{Decentralizáció és partnerség}

A területi decentralizáció Magyarországon több szinten érvényesül, e területi szintek azonban nem egyenlö intézményekkel és kompetenciákkal rendelkeznek. Nem kellöen tisztázott a szintek közötti munkamegosztás, mint ahogy a jogi szabályozás szintjén az sem rendezett kellöképpen, hogy mikor és milyen területi, illetve funkcionális nagyságrendben indokolt és lehetséges a közvetlen központi beavatkozás a decentralizált szervezetek tevékenységébe az ún. kiemelt, illetve válságtérségek esetében. A regionális szint lehatárolása nem történt meg, intézményei és funkciói kialakulatlanok.

A területfejlesztési elosztási döntések, a tervezés decentralizációja és a partnerségi koordináció szempontjából egyaránt megyei szinten történt elörelépés a megyei területfejlesztési tanácsok létrehozásával. Az országos tapasztalatok azt mutatják, hogy ugyan jelentös zavarokat okozott a tanácsok jogi természetének tisztázatlansága, a kellö rugalmasság mégis lehetövé tette a szervezetek felállitását, az első elosztási döntések meghozatalát, a tervezési folyamatok felgyorsulását. A megyei területfejlesztési tanácsok müködési tapasztalataiból az EU-követelmények tükrében az alábbiak emelendök ki:

- A müködés során már felmerültek bizonyos gondok, amelyek elöre jelzik, hogy a jogi státusz bizonytalansága szerepzavarokhoz és konfliktusokhoz vezet. A megyei területfejlesztési tanács kizárhatja a pályázatokból azokat a településeket, amelyek nem csatlakoztak egyetlen társuláshoz sem, vagy 
azokat a társulásokat, amelyek nem fizettek a tanács számára müködési hozzájárulást. Hosszabb távon pedig elkerülhetetlennek látszik, hogy a stratégiai tervezés választott szervezet hatáskörébe kerüljön;

- A tanácsok müködésének szakszerüségét és hatékonyságát egyelöre szinte semmi nem garantálja, hiszen az esetek túlnyomó többségében (három megye kivételével) nincs önálló, megfelelö szakemberrel, kapcsolatrendszerrel és információval (informatikával) ellátott munkaszervezet. Egyértelmüen látszik, hogy a tagok között az egyik legnagyobb konfliktusforrás a költségek megosztása és a munkaszervezet elhelyezése, megalakítása;

- A pénzeszközök felhasználásának folyamatba épitett és utólagos pénzügyi ellenőrzését a kincstár csak megerösitett területi apparátussal tudja elvégezni, mert e nélkül a folyamatok rendkívül lelassulnak. A kincstár szerepvállalása a területfejlesztésben egyébként sokak által vitatott, a jelenlegi szervezeti konstrukcióban azonban már nem célszerü a folyamatokat visszafordítani. A pénzügyi, törvényességi szempontú ellenörzés mellett kell kialakitani a monitoring rendszert valamennyi döntéshozási, illetve forráselosztási szinten.

Az alulról építkező területfejlesztés ma leginkább a kistérségek vonatkozásában érvényesül, ezért müködtetésük, aktivitásuk fenntartása kulcskérdés. E szervezödéseket jelentösen érintette a területfejlesztési törvény, nem kevés konfliktust is okozva. Miközben egyértelmüen helyeselhetö az a kormányzati szándék, hogy a kistérségi szervezetek közelitsenek a statisztikai, illetve kedvezményezett térségek határaihoz, a gyakorlati tapasztalatok azt mutatják, hogy a kormányzati, illetve törvényi ösztönzés eddig alkalmazott módszerei nem elég hatékonyak. Még mindig sok település nem tagja a társulásoknak, $s$ a tényleges tevékenység sok helyen nem a társulásokhoz, tehát a tanácsi képviselethez, hanem a korábbi egyesületekhez, szövetségekhez kötődik, amelyek általában kisebb térséget fognak át, a városok több esetben nem vesznek részt bennük. A törvény szervezeti megkettözödést és nem integrációt eredményezett. Megoldandó probléma az is, különösen az EU-csatlakozás szempontjából, hogy a megyei decentralizáció mértéke lehetővé teszi-e azt, hogy ne csak kedvezményezett térségi beruházást támogassanak a területfejlesztési tanácsok. A koncentráció elve ugyanis elsősorban a kedvezményezett térségekben ösztönzi, illetve teszi lehetővé a támogatások felhasználását.

A törvénybeli szabályozás alapján a területi munkamegosztás leggyengébb szintje a régió, kialakulatlan intézménye a regionális fejlesztési tanács, miután két esettöl eltekintve létrehozása önkéntes, területét a törvény nem igazítja a NUTS 2 szinthez, rögzített forrásai, döntési kompetenciája nincs, csak olyan feladatokat láthat el, amelyeket a megyei területfejlesztési tanácsok a saját feladatkörükböl hajlandóak átruházni. Az eddig létrejött regionális tanácsok egyelöre még a szervezetépítés időszakában vannak, s érezhetően az EU-források elérése motiválja elsősorban a tagokat a megalakulásban.

Részben érthetö, hogy a törvényhozó az önkéntesség és az alulról épitkezés elvéhez ragaszkodva óvatos a megyék közötti társulások ösztönzése, illetve elöirása kérdésében. Ugyanakkor hosszabb távon nehezen lesz finanszirozható és müködtethető egy olyan területfejlesztési intézményi rendszer, amelyben eltér a 
statisztikai, illetve a tervezési szint a ténylegesen mũkődő dőntéshozó szervek illetékességi területétōl. Az sem lenne célszerū, ha szétválna, megkettôzödne az irányitás egy uniós és egy hazai regionális politikai intézményre és tervezési rendszerre.

A hazai partnerségi szervezetekben tőbbnyire az ōnkormányzatok vannak túlsúlyban, regionális szinten a partnerségi szervezetek nem müködnek, ezért szilárd regionális integrációjukra vagy szövetségükre feltétlenül szükség lenne. A partnerség követelményét egyébként nem csak a speciális partnerszervezetek felállitása teljesíti, hanem e szervezetek erōteljesen kooperativ, illetve a társadalmi nyilvánosságot bekapcsoló mükődési mechanizmusa is. Ez egyelöre a mi partnerségi intézményrendszerünkre nem jellemző.

A területfejlesztés irányitásával szembeni fontos követelmény a koordináció, amelynek jelenlegi szabályozása, illetve intézményesitése nem megnyugtató. Ezt az Agenda 2000 különösen a minisztériumok között tartja fontosnak a források koncentrált, hatékony felhasználása érdekében. A hazai Országos Területfejlesztési Tanács s a mellette müködő Országos Területfejlesztési Központ olyan szervezeteknek minősíthetők, amelyek alkalmasak az ágazatok közötti koordinációra. Ugyanakkor a jelenlegi jogosítványok, jogállás és összetétel már jelzi, hogy a tanács nem rendelkezik igazán erős koordinációs befolyással. Területi szinten a koordináció, illetve a forráskoncentráció ugyancsak akadozik: míg a vidékfejlesztési forrásokat például az FM hivatalok osztják el, a területfejlesztésben érintett dekoncentrált szervek csak meghivottak a területfejlesztési tanácsokban. Ósszességében; a koordináció intézményei és mechanizmusai szinte teljesen kialakulatlanok.

\section{Területfejlesztési eszkōzōk}

A koncentráció és az addicionalitás feltételei ma Magyarországon még hiányosak. A területfejlesztési támogatások földrajzi koncentrációján (a kedvezményezett térségtipusok EU-konform lehatárolásán) kívül - ami egyébként nemzeti kompetenciában marad a jövőben is - sem a tevékenységi koncentráció, sem pedig az erőforrások egyesítése nem felel meg az EU-elveknek, illetve trendeknek.

$\mathrm{Az}$ Európai Unió valamennyi támogatott térségében lényegesen nagyobb a munkahelyteremtö, vállalkozástámogató, valamint a humán infrastruktüraberuházások aránya és kisebb a müszaki infrastruktúráé, mint Magyarországon. Az eltérés egy részét infrastruktúránk elmaradottságával lehet magyarázni, egészét azonban nem. A döntési testuletekben résztvevő önkormányzatoknak felül kell emelkedniük saját közvetlen felelösségük túlhangsúlyozásán, a saját politikai népszerüségüket közvetlenül befolyásoló beruházások körén, és nagyobb hangsúlyt kell helyezni a vállalkozástámogatásra, a vállalkozási kömnezet megteremtésére. Ha nem így lesz, akkor maga az önkormányzati magatartás lesz az egyik fó oka a területfejlesztési döntésekbe való nem kielégítö bevonásuknak. A gazdaságfejlesztés súlyának növekedéséböl következik, hogy a koncentrált munkahelyteremtés szempontjából kedvezőbb feltételeket nyújtó térségi centrumok felértékelődnek.

A területi fejlōdést befolyásoló források szétaprózottak, jelenleg kilenc tárca osztozik a támogatásokon. A forráskoordináció gyenge. Elengedhetetlen, hogy a fejlesztési eszközök egységes kezelésének, regionális elosztásának és 
felhasználásának mechanizmusa kiépüljön. A magyar önkormányzatok igen sokféle támogatásban részesülnek, a kiegyenlitő mechanizmusok eltérő irányultságúak, különböző alapelvek szerint müködnek.

A magyar önkormányzati rendszer a közösségi szektoron belül túlsúlyos és intézményfenntartó-centrikus, ez pedig a területfejlesztési politika tekintetében rontja a tisztánlátást, ugyanis nincs megfelelö kép a reális pénzügyi - a feladat és forrás összevetéséböl származtatható - egyenlötlenségröl, igy célt téveszt a kiegyenlítési eszköz- és célrendszer (pl. pénzügyi hiányok keletkezhetnek magas ellátottsági mutatók mellett is). A területi önkormányzati szint nem tud átfogó térségpolitikai cél- és eszközrendszert müködtetni. A mobilizálható (és egyre szükülö) önkormányzati vagyon köre csekély, az önkormányzatok hitelképessége (garanciák hiánya miatt is) gyenge, forráshiányos költségvetésük mellett alapvető intézményfenntartási, müködtetési gondokkal küszködnek, szabad forrásaik gyakorlatilag alig vannak. Ez érvényes a regionalizáció szempontjából meghatározó nagyvárosokra és az illetékeken kívül saját bevételekkel alig rendelkező megyei önkormányzatokra is.

A közvetlenül területfejlesztési célú pénzeszközök nagyságrendje más alapokéhoz képest elenyésző. A különböző alapok célmeghatározási-, elosztási-, elbírálási rendje alig harmonizál egymással, a területi szempontoknak is eleget tevő összehangolás, koordinálás, egyeztetés és megfeleltetés kívánalma ma még csak kormányzati igényként, semmint gyakorlatként jelenik meg, továbbra is az ágazati szemlélet és érdekérvényesítés túlsúlya tapasztalható.

A társfinanszirozás biztosítása nemcsak mennyiségi-, hanem igazgatási követelményeket is felvet. Az EU-támogatás engedélyezésének elöfeltétele, hogy mind a központi kormányzat, mind az önkormányzat, mind az esetleges magánbefektetôk részéröl a projekt egész időtartamára vonatkozó pénzügyi kötelezettségvállalás a pályázat beadásakor mellékelve legyen. Ez a követelmény Magyarországon, ahol többéves költségvetési tervezés nem, vagy alig létezik, meglehetős nehézségeket vet fel. A szabályozás gyakorlatilag évente jelentősen változik, így a többéves kötelezettségvállalás aránytalanul kockázatos. Az EU-finanszírozás tehát ơsszekapcsolódik az egész szabályozási rendszer továbbfejlesztésével, a szabályozás stabilabbá tételével. E nélkül érdemi támogatás elnyerése lehetetlen.

\section{Összegzö értékelés}

Elemzésünk végső mérlege a hazai területfejlesztési politika pozitív egyenlegét mutatja. Az eddigi változások, az előkészületben lévő dokumentumok főbb megállapításai egy merőben új, az európai trendekhez hozzásimuló politika körvonalainak kibontakozását sejtetik. Bár az e politikára leselkedő veszélyek sem becsülhetők le, számos gyenge elemet is felsorolhattunk, a regionális politika erősségei és nem utolsó sorban az európai integrációhoz való közeledéssel párhuzamosan megszaporodó lehetőségei révén a területfejlesztés remélhetőleg az ezredfordulóra a modernizálódó Magyarország egyik meghatározó részpolitikájává válik, és modellként szolgálhat Kelet-Közép-Európa többi országa számára is. Az átalakulás szükséges irányait összegző 9. táblázatból láthatják, hogy az elöttünk álló feladatok megoldásában csak a kezdeti lépések legelejẹ́n vagyunk, ahhoz, hogy az ezredforduló után cél-, eszköz- és intézményrendszerében konzisztens regionális 
politikáról beszélhessünk, az új területfejlesztési kerettörvényhez kapcsolódó számtalan jogszabályra, gazdasági eszközre és politikai döntésre lesz szükség.

\section{TÁBLÁZAT}

A magyar regionális politika EU-kompatibilitása (Compatibility of Hungarian regional policy with the EU regulations)

\begin{tabular}{|l|l|c|}
\hline \multicolumn{1}{|c|}{ A politika } & & $\begin{array}{c}\text { Az EU-kompatibilitás } \\
\text { foka }\end{array}$ \\
\hline Célja & Szerkezetátalakítás & ++ \\
\hline Alanya & Megye/kistérség & + \\
\hline Tárgya & $\begin{array}{l}\text { A piac negatív hatásainak } \\
\text { mérséklése/innováció }\end{array}$ & ++ \\
\hline Célcsoportja & $\begin{array}{l}\text { Problematikus körzet } \\
\text { (elmaradott, depressziós, } \\
\text { rurális) }\end{array}$ & +++ \\
\hline Eszközei & Területfejlesztési célelöirányzat & + \\
\hline Finanszírozásának módja & „Decentralizált” & + \\
\hline Ösztönzésének formája & Mérlegelö & ++ \\
\hline $\begin{array}{l}\text { Irányitásának centruma } \\
\text { Országos Területfejlesztési } \\
\text { Tanács }\end{array}$ & +++ \\
\hline $\begin{array}{l}\text { Végrehajtásának } \\
\text { meghatározó eleme }\end{array}$ & Megyei területfejlesztési tanács & + \\
\hline $\begin{array}{l}\text { Fejlesztésekre gyakorolt } \\
\text { hatása }\end{array}$ & Elszigetelt & + \\
\hline $\begin{array}{l}\text { Domináns kedvezmé- } \\
\text { nyezett ágazatai }\end{array}$ & Infrastruktúra & + \\
\hline $\begin{array}{l}\text { Népességi hatóköre } \\
\text { Közvetlen } \\
\text { finanszírozásának } \\
\text { mennyisége }\end{array}$ & 29\% & ++ \\
\hline
\end{tabular}

+++ Magas

++ Közepes

+ Alacsony

Az új magyar területfejlesztési politikát, a nyugat-európai nemzeti és az Európai Unió közös regionális politikáit összevetve még mindig jelentös különbségeket regisztrálhatunk. A legfontosabb eltérések:

- A regionális fejlesztés támogatására Nyugat-Európában - a regionális különbségek mértékének függvényében - sokkal jelentősebb összegeket fordítanak, mint Magyarországon. Nem ritkán a támogatások volumene a nemzeti GDP $2-4 \%$-át is eléri, bár a pénzügyi ösztönzés forrásainak jelentös része nem a nemzeti költségvetést terheli, az EU-támogatás formájában érkezik; 
- Azokban az országokban, ahol az innováció domináns teruleti koncentrációt mutat (egyetlen központban összpontosul), a regionális politikát - saját eszközein kívül - az egyes tevékenységek decentralizálását szolgáló törvények is erösítik;

- A kijelölt problematikus térségek között a támogatások elosztása, a mérlegelő (diszkrecionális) jellegủ támogatási igazgatás ellenére viszonylag egyenletes, Magyarországon viszont az észak-keleti megyék - részben politikai okokból - demográfiai súlyuknál aránytalanul magasabb támogatásokban részesültek;

- A támogatások ágazati irányultsága Nyugat-Európában a feldolgozóipar és az exportképes szolgáltatások, Magyarországon viszont eddig túlsúlyban volt az infrastruktúra. A csekély számú munkahelyteremtő ipari és szolgáltatási beruházás számára sem volt követelmény, hogy a foglalkoztatotti létszám növelésén túl járuljon hozzá a térségi kohézió erösitéséhez;

- A regionális fejlesztési támogatások irányítását végző szervezeti-rendszer Nyugat-Európában - az államszervezet filozófiája fúggvényében országonként sok sajátosságot mutat. Általános tendencia azonban a decentralizáció, még azokban az országokban is jelentős szerepet juttatnak a területi önkormányzatoknak a támogatások véleményezésében ès felhasználásának befolyásolásában, ahol a központi államszervezet meghatározó szerepet játszik a regionális politika irányitásában, a területi őnkormányzatok kompetenciája pedig erōsen korlátozott;

- A területfejlesztés szabályozásának célja mindenütt a nemzeti regionális fejlesztési stratégia sikeres megvalósítása. Még a legaprólékosabban kimunkált törvény is súlytalanná válik, ha alkotói nem stratégiai célok alapján fogalmazzák meg javaslataikat.

\section{A csatlakozásig elvégzendö feladatok}

Az Európai Unióhoz való csatlakozás, változtatásokat kővetel majd, annak érdekében, hogy a hosszú távon jelentôsen kibővülő regionális finanszírozási források felhasználása hatékony legyen. Mintegy összefoglalásául eddigi megállapításainknak, vegyük sorra a legfontosabb teendöket.

\section{Forráskocentráció és a finanszirozás reformja}

A csatlakozás érdekében nagyon célszerủ lenne, ha az államháztartási reform keretében bizonyos - a regionális politikát érintö - kérdések megoldásra kerülnének. Először a kiegyenlítő mechanizmusok területén lenne erre szükség: a magyar önkormányzatok igen sokféle támogatásban részesülnek, de ezek eltérő irányultságúak, különbözỏ alapelveken nyugszanak, ezért nem lehet egyértelmüen megállapitani, mit tesz a magyar kormányzat az eltérô gazdasági- és forrásadottságú önkormányzatok helyzetének kiegyenlitésére. Az EU-n belül - de különösen Németországban - ez az o̊nkormányzati finanszirozás egyik legfontosabb eleme (Finanzausgleich), és egyúttal ez irányú tevékenységünk, erőfeszitéseink elismerésének egyik fontos kritériuma lehetne. De saját tisztánlátásunk érdekeit is szolgálná egy világos kiegyenlitō mechanizmus megteremtése. 
A második problémakörbe a már többször említett területfejlesztési célú támogatások tartoznak. Jelenleg kilenc tárca osztozik a támogatásokon a koordináció szükséges szintje nélkül, ezért nem vagyunk képesek egységesen és összehangoltan a „saját hozzájárulást” a potenciális EU-támogatásokhoz hozzátenni, és azt garantálni. Elengedhetetlen ezért, hogy a fejlesztési eszközök egységes kezelésének, regionális elosztásának és felhasználásának mechanizmusa kiépüljön.

A programfinanszírozás elöfeltétele, hogy a támogatási források hasonló alapelvek szerint rendszerszerüen müködjenek, a közöttük lévö koordináció intézményes formában biztositható legyen. Nagyszámú és sok tárca hatáskörébe tartozó források esetében ez az elöfeltétel nehezen biztositható. Ezért, illetve a regionális decentralizáció hatékonyabb szervezése érdekében a támogatási formák számát csökkenteni célszerü. A koncentráció egyben a közvetlen területfejlesztési források nagyságrendjének jelentős bővítését szolgálja.

A kormányzati felelősségvállalásban hangsúlyeltolódás szükséges, önálló és határozott területfejlesztési politika megvalósitását biztosító költségvetési-finanszírozási rendszer kimunkálása indokolt. Ez megkőveteli a kormányzati koordináció erősítését és a regionális szempontok markáns megjelenítését a kormányzati pénzügyi döntési mechanizmusokban.

Az EU-támogatásokhoz való hozzájutás a központi és az önkormányzati költségvetés szerkezetében változtatást igényel. Célszerünek látszik, hogy külön müködési és külön fejlesztési költségvetés készüljön. Indokolt az állami alapok és célelöirányzatok olyan átrendezése, amely lehetővé teszi a közfeladatok finanszírozásának és a fejlesztés támogatási rendszerének szétválasztását (müködési vagy egyértelmüen szociális finanszirozás, pl. ne történjen fejlesztési célú alapokból és célelöirányzatokból). Hosszú távon arra kell törekedni, hogy a fejlesztési források az elsődleges célok szerint differenciálódva elkülönült pénzügyi alapokban jelenjenek meg. Ez az alapok és célelöirányzatok összevonását és átstrukturálását is jelenti.

A kohéziós politikai célok finanszírozásának másik alapkérdése az EU-támogatásokhoz rendelt nemzeti (költségvetési, önkormányzati, magán) források mennyisége. A Kohéziós Alapból kapható támogatások esetében a saját hozzájárulás aránya $15 \%$, a Strukturális Alapokból származó támogatásokhoz $25-50 \%$.

Elvileg nem kizárt, gyakorlatilag azonban kivitelezhetetlen, hogy a nemzeti rész csak központi kormányzati kötelezettségvállalással történjen, ezért a területfejlesztésben érintett és érdekelt szereplöket kell olyan helyzetbe hozni, hogy érdemi saját forrással rendelkezzenek, és kapjanak forrásonként eltérō szerepet az állami támogatások elosztásában.

A támogatások tényleges folyósítása általában igen lassú és bürokratikus, ezért tisztázni szükséges, hogyan, milyen csatornákon történhet a pénzek megelölegezése. Erre, valamint a pénzkezelésre - a versenyeztetés követelményeinek eleget téve alkalmas lehetne egy bank vagy a kincstár is. Önmagában ez a momentum is erősítheti a pénzintézeti szféra decentralizációját és/vagy a kincstár területi hálózatát. 
A finanszírozási rendszer hatékonyságát fokozza a kőzponti kormányzat, a régió és a területfejlesztés többi szereplöje között létrejövö tervszerzödések mechanizmusa, a különbőző források egyesítésének és felhasználásának jogi-pénzügyi kötelezettségeit tartalmazó dokumentum.

A kőltségvetés a stratégiai programokban, a Nemzeti Fejlesztési Tervben programfinanszírozás keretében határozza meg a strukturális támogatási célokat, az állami hozzájárulás nagyságrendjét, az önkormányzatok, a gazdasági szféra számitásba veendö forrásait. Mindezek során rögzítendő a területfejlesztési, valamint a külfơldi forrásokból e célra biztositható összegek nagyságrendje. A lakossági források bevonására, a befektetők megnyerésére jelentős szemléletváltást is eredményező külön program dolgozandó ki.

$\mathrm{Az}$ önkormányzati finanszírozást olyan irányban kell fejleszteni, hogy minden önkormányzat részére elegendő forrás jusson a kötelezö feladatok ellátására, s lehetővé váljon a forrásképzés az önként vállalt feladatok, a pótlás és a fejlesztések megvalósítására, a területfejlesztési célokhoz való hozzájárulásra. Erre a támogatások, a megosztott és saját források együttes osszzegének kell fedezetet nyújtania. Ez a rendszer eredményezheti, hogy mind az önkormányzatok, mind a különbözö területfejlesztési szereplök részt tudjanak venni a fejlesztések finanszírozásában. Ennek másik oldala, hogy az önkormányzati helyi fejlesztések finanszírozása alapvetően az önkormányzati és a helyi gazdasági forrásokból történjen. Alanyi jogon csak akkor van szükség központi támogatásra, ha egy helyi fejlesztési cél országos probléma megoldását segíti elö, beruházási költségigénye igen magas, megtérullésére csak hosszú távon van remény, és egyéb források bevonása nehézkes.

$\mathrm{Az}$ állami támogatás szerepének és arányának csőkkentése mellett a saját bevételek növelése, az önfinanszírozó képesség javítása, a helyi adók struktúrájának átalakitása (esetleg a pótadóztatás bevezetése) teremtheti meg az önkormányzati önrész biztositásának alapvető kereteit, azt, hogy az önkormányzati szféra - a költségvetési tervezés változtatásának követelményeivel együtt - elöre kötelezettséget tudjon vállalni.

A finanszirozási rendszerbe olyan automatizmusokat kell beépíteni, amelyek lehetővé teszik a több évre tervezést, és csak igen szük sávban engedélyeznek mozgásokat, eltéréseket annak érdekében, hogy a kötelező vállalásoknak a pénzügyi tervben foglalt ütemezésben és módon az önkormányzatok eleget tudjanak tenni.

A jövöben kívánatos helyzetet olyan forrásrendszer alkalmazása biztosithat az önkormányzati szférában, amely segíti a pénzügyi önállóság növelését, egyúttal biztosítja a kiegyenlitést is az eltérő jövedelmi kapacitású önkormányzatok között. A pénzügyi önállóság növelésének a hazai viszonyok között alapvetően két útja lehet. Az egyik a megosztott személyi jövedelemadó bevételi rendszer átalakitása központi és helyi döntésüvé, a másik a helyi ingatlanadó, az értékalapú ingatlanadóztatás alkalmazása. Ez elsősorban a városi önkormányzatok számára jelenthet bevételi forrást. A helyi adók közül az értékarányos ingatlan adóztatásra való áttérés szükségessége fogalmazható meg. Ehhez azonban tőbb feladatot kell megoldani, mint pl. értékelési törvény megalkotása, képzési programok elindítása, a lakosság felkészitése. A személyi jövedelemadó hosszabb távon az onkormányzati gazdálkodás egyik alapvető finanszírozási eleme marad, hangsúlyosan jeleníti meg a 
jövedelem-kiegészítési mechanizmus mükődését az önkormányzati finanszírozás területén, a fejlesztéseket segíti a céltámogatási rendszeren keresztül (az iparüzési adó szerepével, jövőjével kapcsolatban egymással ellentétes nézetek fogalmazódnak meg).

E rendszer csak akkor lesz müködőképes, ha az önkormányzatokat érintő feladatés hatáskör reformot szisztematikusan végrehajtják, a kompetencia-szinteket tisztázzák. A hosszabb távon is forráshiányos kistelepülési önkormányzatok feladatainak csőkkentése, a szolgáltatások integrált, társulásos megszervezése mellett szükséges lesz a területfejlesztéstől elkülönülő települési kiegyenlítö rendszer müködtetése is.

\section{Régióépités}

Magyarország EU-csatlakozásának, illetve a Strukturális Alapokból történő támogatások igénybevételének előfeltétele olyan nagyrégiók (NUTS 2 egységek) kialakítása, amelyekre fejlesztési koncepciók és azok megvalósítását szolgáló programok dolgozhatók ki.

Az EU tagállamaiban kialakított 206 NUTS 2 régió közjogi-közigazgatási helyzete, területe, népességszáma rendkívül eltérö. Lényegét tekintve nemzeti meghatározottságú egységekről van szó, ugyanakkor minden ország NUTS 2 rendszere megfelel az egységes követelményeknek, valamennyi statisztikai (számbavételi, elemzési), tervezési (programozási, koordinációs) és területfejlesztési (támogatáspolitikai, decentralizálási) egység.

A tíz kelet-európai társult országban a mezoszintü közigazgatási egységek száma 357, abban az öt országban, amelyekkel a tárgyalásokat megkezdik, 250 (ebböl Szlovéniában 147). Egyértelmü, hogy az EU ennyi területi egységet, mint a támogatás alanyait, kezelni nem tudja. Elengedhetetlen tehát e célt szolgáló nagyobb teruleti egységek képzése.

A NUTS-rendszer kialakításának, s azon belül a kulcsszint, a NUTS 2 létrehozásának alapkérdése, hogy a magyar állam az EU-csatlakozás előtt milyen mértékben gondolja újra állami berendezkedésének, müködésének mikéntjét, s hogyan oldja meg vagy hagyja változatlanul a közigazgatás területi struktúráját.

Nincs külső EU-kényszer a magyar állami berendezkedés, közigazgatás módosítása tekintetében. A jelenlegi magyar struktúrák némi módosításával is ki lehet alakítani az EU regionális politikájához illeszkedő szervezeti és területi struktúrákat.

A NUTS-rendszer, s azon belül a NUTS 2 szint tényleges lehatárolása az EU szempontjából tekintve belügy, ami azt jelenti, hogy néhány általános jellegũ kritériumon kívül nincsenek abszolút EU-elvárások a lehatárolással szemben, igy a magyar érdekelteknek kell közös nevezőre jutniuk.

Megítélésünk szerint az OTK 1997. júniusi változatában, mintegy elvi jelentőséggel megfogalmazott $5-6$ potenciális NUTS 2 egység, s a hét javasolt tervezési-statisztikai régió (Nyugat-Dunántúl, Közép-Dunántúl, Dél-Dunántúl, Közép-Magyarország, Észak-Magyarország, Észak-Alföld, Dél-Alföld) között belsô ellentmondás feszill. Az OTK legutóbbi tervezetében, mintegy kizárólagos lehetőségként megjelenített hét tervezési-statisztikai régió mellett javasoljuk visszavenni az 1971-től többször újragondolt hatos felosztást, amely abban tér el az 
OTK mostani javaslatától, hogy a Dunántúl területén csak két tervezési-statisztikai régiót javasol.

A területfejlesztési régiók lehatárolásakor figyelembe veendö föbb szempontok az alábbiak:

- a regionális együttmüködés elötörténete, a területi kohézió esélye;

- az ország térszerkezete szempontjából vett arányosság;

- a regionális politika alapcéljait tekintve a viszonylagos területi homogenitás;

- a régiók müködőképes belső tagolódása (központ, alközpontok, együttmüködési készség és képesség stb.), a közigazgatási határok követése;

- a régióba tömörített egységek már megvalósuló vagy kívánatos „geopolitikai” hasonlósága, a hosszú távon meghatározó nemzetkőzi orientációk közelsége;

- a létrehozás és mükődtetés költségei (a dőntéshozatali, dőntés-elökészitő és szakmai-adminisztrációs háttér intézmények, információs, tervezési, menedzselési és ellenörzési-monitoring tevékenységek szervezete, decentralizált finanszírozás intézményrendszere stb.), a funkció szempontjából vett méretgazdaságosság.

Mindezek alapján a hatos felosztás mellett több érv szól, amelyek közül a legfontosabbak az alábbiak:

- történetileg megalapozottabb a Dunántúl kettes, mint hármas felosztása;

- a Dunántúl kétrégiós felosztása során létrejövő területi egységek belső kohéziója erősebb, és a belsö erőforrások alapján prognosztizálható fejlödési pályák is az ilyen megosztásban formálódó térségi együvé tartozást valószínüsítik;

- a további osztódás az ország egészét tekintve térszerkezetileg felesleges fejlesztési párhuzamosságok kialakulásához vezetne;

- a két egységnek - bár eltérō jellegũ és fejlettségũ - területileg elfogadott regionális központja van, egy harmadik regionális kőzpont kialakulásának minimális az alapja és az esélye.

A kialakítandó régiókat a 4. ábra mutatja.

Ebben a helyzetben a kormány és a parlament felelössége és döntésképessége a meghatározó. A regionális egységek meghatározásakor elsődlegesen nem a partikuláris érdekeket s nem csak a pillanatnyi, rövid távú területi anyagi előnyöket kell szem elött tartaniuk, hanem az EU-struktúrákhoz való fokozottabb illeszkedést, valamint az ország, s a „Dunántúl-vitában” a térség hosszú távú strukturális érdekeltségét.

A régiók kijelölését követően pontositani kell e régiók fejlesztési tanácsainak szabályozását. Részletesen meg kell határozni feladataikat, szervezeteiket és eszkőzeiket.

- A regionális fejlesztési tanácsok illetékességi területét a NUTS 2 egységekhez kell igazitani. Ezt a területfejlesztési törvény módositásával lehet megoldani, amely elöírná, hogy a kormányzati és területi érdekegyeztetés színtereként létre kell hozni e régiókban a tanácsokat. A kormánynak joga van kezdeményezni a regionális fejlesztési tanácsok 
létrehozását, s ha deklarálja, hogy csak ezekben a területfejlesztési tanácsokban hajlandó részt venni, talán önkéntes alapon is elérhető a megyék csatlakozása;

- Egyértelművé kell tenni a törvényben és az Országos Területfejlesztési Koncepcióban használt régiófogalmak (tervezési, funkcionális, fejlesztési és programrégió, kiemelt térség) és az intézményrendszer kapcsolatát. A kormányzat részvételével müködő, saját forrásokkal és hatáskörrel rendelkezỏ régió a hat NUTS 2 egység legyen, e struktúrának nem eleme a Budapesti és a Balatoni Regionális Fejlesztési Tanács;

\section{4. ÁBRA}

Javasolt területfejlesztési régiók Magyarországon

(Proposal for the territorial units of regional policy in Hungary)

A hat régiós beosztási javaslat

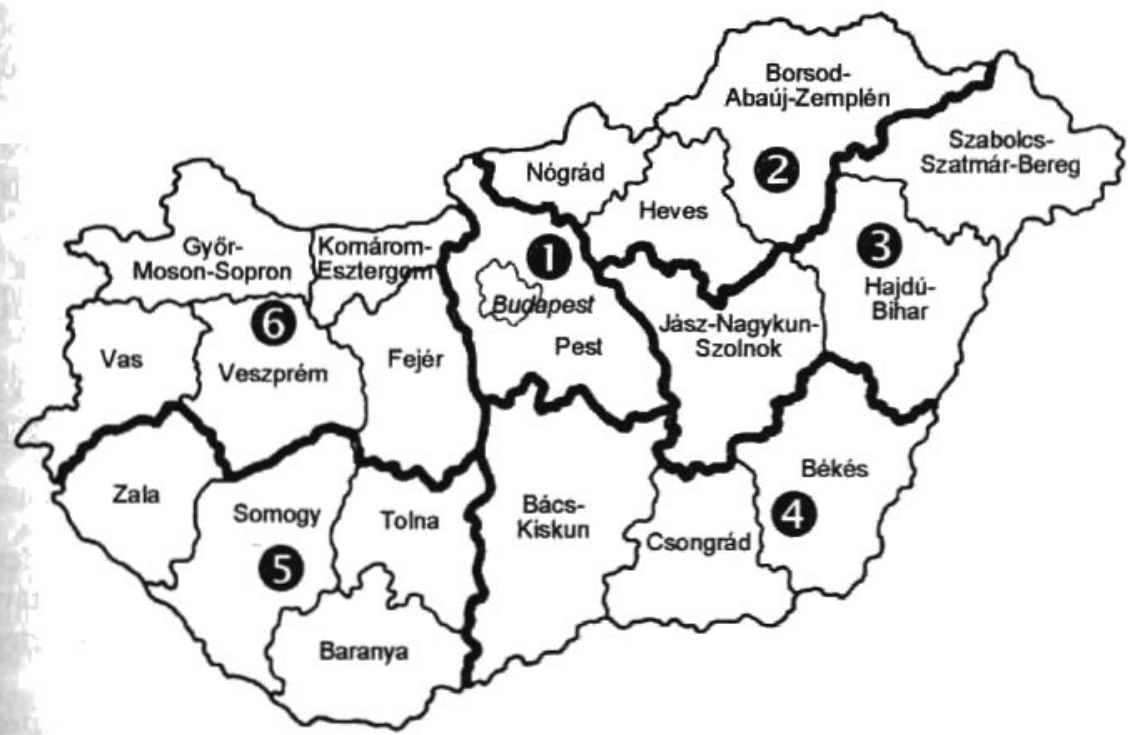

Jelmagyarázat: 1-Központi körzet, 2-Észak-Magyarország, 3-Észak-Alföld, 4-Dél-Alföld, 5 -Dél-Dunántúl, 6 -Észak-Dunántúl

- A regionális fejlesztési tanácsnak törvényben szabályozott saját forrásokkal kell rendelkeznie, s rögziteni kell azt is, hogy az EU-támogatások elsődleges kedvezményezettjei a régiók. A forráskoncentráció, illetve az ágazati források integrációja azt igényli, hogy a területfejlesztési újraelosztás elsődleges címzettjei a régiók legyenek. Megyei szinten már elsősorban települési és kistérségi önkormányzati infrastrukturális források felett szülessenek döntések, amelyben a méltányossági, illetve a kiegyenlítỏ célok érvényesülhetnek; 
- A regionális fejlesztési tanácsok összetételében változtatásokra lenne szükség, hogy képviselethez jussanak a megyeszékhelyi városok is, nem feledve azt, hogy az EU regionális politikájában felértékelödőben van a nagyvárosok szerepe. A kistérségi társulásoknak, kamaráknak és a munkavállalóknak egy-egy képviselöjét kellene a tanácsba küldeni. Hosszabb távon a kamaráknál különösen indokolt lehet a regionális integráció, amire a kamarai törvény lehetőséget ad. Ki kell dolgozni a regionális tanácsok és az ágazati igazgatási szervek közötti kapcsolatrendszert;

- A regionális fejlesztési tanácsnak ne származtatott hatásköre legyen, hanem a törvény rögzitse a feladatokat, figyelembe véve azt, hogy oda kerülne a területfejlesztési decentralizált források és a nemzetközi források zöme, s ez a szint a kormányzati és területi érdekegyeztetés fontos eleme. A törvényben rögzitett feladatok között különösen fontos az általános gazdaságfejlesztési szerepkör, a nemzetközi regionális együttmüködésekben való részvétel, a nagy infrastrukturális hálózatok fejlesztése, környezetvédelmi szempontból fontos fejlesztések, az innovációhoz, technológiai transzferhez kapcsolódó tevékenységek, az alsóbb szintủ tervezés szakmai támogatása.

$\mathrm{Az}$ ország területi szerkezetének állapota, a területi fejlödést a jövöben befolyásoló tényezök regionális különbségei, kiváltképpen pedig a belső erőforrásokra alapozott fejlesztési paradigma elötti akadályok felszámolása, a területfejlesztés decentralizált irányitása szervezeti és finanszírozási feltételeinek a kialakitása érdekében valamennyi régióban sürgető feladatnak az alábbiak tekinthetök:

- a regionális fejlesztési tanácsok megalakitása, a regionális programokat szervezö munkaszervezet létrehozása, a régió fejlesztési koncepciójának és programjának a kidolgozása;

- a humán erőforrások fejlesztésére képes intézmények megszervezése;

- a régiók megkőzelíthetőségi viszonyainak javítása, a regionális közlekedésfejlesztési koncepciók kidolgozása (tekintetbe véve az ország hosszú távú koncepcióját és a régió gazdaságfejlesztési szükségleteit), új fejlesztési feladatok (pl. regionális repülöterek) megfogalmazása;

- a régiók gazdasági versenyfeltételeit javitó tevékenységek (iparfejlesztési pólusok, $\mathrm{K}+\mathrm{F}$ szervezetek, technológiai centrumok) programszerü fejlesztésének egyeztetése, az üzleti szolgáltatások bővítése, a belső kohézió erősitése;

- a fenntartható fejlődés környezeti követelményeinek meghatározása, a környezeti terhelés mérséklése, a védett teruletek speciális fejlesztési programjainak harmonizálása a régió gazdaság- és infrastruktúra-fejlesztési elképzeléseivel;

- az alacsony gazdasági színvonalú agrárterületekre komplex vidékfejlesztési koncepció összeállítása, alternatív foglalkoztatási lehetőségek, környezetvédelmi, szociális fejlesztési programok kidolgozása;

- a regionális kultúra, a területi identitást erösítő tömegkommunikációs és müvelödési szervezetek összehangolt fejlesztése; 
- a régió európai interregionális szervezetekhez való kapcsolódásának megszervezése, a globális területi munkamegosztásban pozíciók megszerzése, határ menti kooperációk fejlesztése.

\section{A támogatások új elosztási mechanizmusa}

A Strukturális Alapok és a Kohéziós Alap létrehozása nem egyszerüen szolidaritási akció az EU részéröl, hanem a tapasztalatok szerint egyértelmü szulkségszerüség is. Az egységes piac létrejötte ugyanis önmagában a regionális differenciák növekedése, az elmaradott körzetek még nagyobb arányú elmaradása irányában hat. 1990 óta a piacgazdaság kialakulásával, majd az áru- és tökemozgás liberalizálásával ezt Magyarországon is tapasztaljuk. A különbségek növekedésének legföbb tényezője a szegényebb régiók termelésének a nagyarányú piaci részesedés csőkkenése saját piacaikon, térségükben. Az Unióba való belépéssel ez a folyamat nagymértékben felerösödhet. Ezt a differenciáló folyamatot a Strukturális Alapokon keresztül történö nagyarányú töketranszfer éppen, hogy ellensúlyozni tudja, ami abban is megmutatkozik, hogy e transzfer ellenére a legfejlettebb és legfejletlenebb régiók közötti különbség és általában a fejlettség regionális szóródása az Európai Unióban az utóbbi évtizedben alig csökkent.

Jótékony hatásai mellett a Strukturális Alapoknak az érintett országok, régiók gazdaságpolitikájára kétségtelenül torzitó hatásai is vannak. A ko-finanszírozás követelménye a szükös nemzeti forrásokat is azokhoz az ágazatokhoz és régiókhoz köti, ahol EU támogatás felhasználása lehetséges, és ez nem biztos, hogy mindig, mindenhol egybeesik a nemzeti preferenciákkal. Erre Magyarországon is van példa. Az EU - precedens-értékü lépésként - 150 millió ECU-t engedélyezett 1996-ban a Strukturális Alapokból Unión kívüli országoknak a vele határos régiók fejlesztésére. Ezt a pénzt - és a hozzá tartozó nemzeti társfinanszírozást - Magyarországnak olyan régiókban kellett felhasználnia (Györ-Moson-Sopron és Vas megyékben), amelyeket saját preferenciarendszerében a legkevésbé támogatott volna.

Az EU támogatásait dőntően infrastrukturális fejlesztésekhez adja és nem, vagy kevésbé támogatja azokat a fejlesztéseket, amelyek már egyébként is telitett piacán konkurenciát jelentenének. (Nem lehet pl. támogatást kapni ültetvénykultúrák növelésére, állattenyésztési beruházásokra, a textilipar fejlesztésére, stb.) A nagyarányú infrastrukturális beruházások társfinanszírozási követelménye azonban elvonja, elszivja, leköti még azokat a nemzeti forrásokat is, amelyek egyébként a fenti ágazatokra - az alacsonyabb munkaerö-költségekből fakadó versenyképességük kihasználására - fordíthatók lennének.

A viszonylag nagyvonalúan ajánlott környezetvédelmi támogatásoknak, az azokból létrehozott létesítményeknek is - pozitiv hatásaik mellett - van olyan következményük is, hogy a hazai termelési költségeket az indokoltnál nagyobb mértékben megdrágítják, ezáltal versenyképességüket veszélyeztetik, miközben a társfinanszírozás révén ugyancsak lekötik fejlesztési forrásaink egy részét.

Az EU-támogatásoknak tehát egyaránt van versenyképességet növelő és versenyképességet csökkentő hatásuk. Gondosan mérlegelni kell ezek eredö hatását. A transzeurópai hálózatok kiépítésének is van piacbővitő (amennyiben a külső piacok jobban elérhetök) és piacszükitö hatása (amennyiben a mi piacaink is a 
külföld számára jobban elérhetővé válnak). Ez esetben azonban valószínüleg a versenyképesség egyéb tényezői azok, amelyek meghatározzák az eredő hatást.

Végül, az EU-támogatásokra vonatkozó kilátások jelenleg sajátos időbeli dilemmát okoznak több szempontból:

- Egyrészt az EU támogatáshoz füzött remények logikusan arra késztetnek, hogy halasszuk el azokat a fejlesztéseket, amelyek később az EU Strukturális Alapjaiból megfinanszírozhatók lesznek. Ezek éppen a kevésbé fejlett régiók felzárkóztatására, infrastruktúrájuk kiépitésére szánt fejlesztések. Hiszen a most végrehajtott, vagy akár a már megkezdett fejlesztéseket saját szükös erőforrásainkból kell megvalósítanunk, míg a belépés időpontja után megkezdett fejlesztésekhez 50-75\%-os, a Kohéziós Alapból akár 90\%-os támogatást kaphatunk. Ez a körülmény az ilyen fejlesztések elodázására, késleltetésére ösztönöz;

- Másrészt a területi különbségek és feszültségek Magyarországon növekednek és félö, hogy bizonyos folyamatok néhány éven belül visszafordíthatatlanná válnak, így ezek a halasztások mulasztásnak bizonyulnak.

$\mathrm{Ez}$ a dilemma nagy feszültséget és bizonytalanságot visz a magyar gazdaságpolitikai döntéshozatali folyamatba. Feloldására csak akkor lenne lehetőség, ha az Unió a csatlakozás előtt hozzáférhetővé tenne támogatási csatornákat, ezáltal megelözve bizonyos folyamatok visszafordíthatatlanná válását.

Az Európai Unióhoz való csatlakozás után Magyarország a Strukturális Alapokból - feltételezve, hogy az elosztás rendje az új tagállamok számára nem módosul kedvezőtlen irányban, és Magyarország, abszorbciós képessége alapján GDP-jének 4\%-át kapná támogatásként - szakértői becslések szerint 1,4 milliárd ECU új erőforrásra számíthat. Nem közömbös, hogy ez az összeg miként oszlana meg az ország régiói között.

A támogatások elosztásában alkalmazott uniós módszert (amely 25\%-os súllyal az ország fejlettségét, 50\%-os súllyal az adott régió GDP-jének a közösségi átlagtól való eltérése, $25 \%$-os súllyal pedig a térség problematikus jellegét veszi figyelembe a munkanélküliségi ráta alapján) használva a magyar régiókban az egy före jutó támogatás kiegyenlítettebb lenne a jelenlegi területfejlesztési támogatások eloszlásánál. Ez természetes is, hiszen az EU szempontjából Magyarország egész területe minősül elmaradottnak, a nemzeti területfejlesztés pedig csak az országos átlaghoz viszonyított elmaradottságot veszi alapul (10. táblázat). A hazai területfejlesztési támogatások azonban az 1991-95 időszakban a hazai beruházásoknak 0,8\%-át, a GDP-nek 0,1\%-át tették ki. Ugyanakkor a kormány által finanszírozott és a Strukturális Alapok támogatási céljai közé tartozó beruházásokra a magyar központi költségvetés és az önkormányzatok a GDP-nek átlagában 9\%-át költötték, de ennek területi megoszlása teljesen más, mint a szüken értelmezett területfejlesztési célelöirányzaté. 


\section{TÁBLÁZAT}

A nagyrégiók részesedése a Strukturális Alapok finanszirozási körébe tartozó beruházásokból

(Share of Hungarian regions of the investments supported by Structural Funds)

\begin{tabular}{|l|c|c|c|c|}
\hline \multirow{1}{*}{ Régió } & $\begin{array}{c}\text { Az 1991-96. évi } \\
\text { területfejlesztési } \\
\text { támogatásokból } \\
\text { való részesedés } \\
\%\end{array}$ & $\begin{array}{c}\text { Az 1992-95. } \\
\text { évi összes állami } \\
\text { beruházásokból való } \\
\text { részesedés } \\
\%\end{array}$ & $\begin{array}{c}\text { Az EU-támoka- } \\
\text { tás hipotetikus } \\
\text { aránya } \\
\%\end{array}$ & $\begin{array}{c}\text { Támogatási } \\
\text { összeg } \\
\text { millió ECU }\end{array}$ \\
\hline Észak-Dunántúl & 2,7 & 19,4 & 17,1 & 239 \\
\hline Dél-Dunántúl & 3,7 & 11,5 & 13,0 & 182 \\
\hline Dél-Alföld & 5,2 & 9,7 & 14,1 & 198 \\
\hline Észak-Alföld & 44,1 & 11,7 & 18,0 & 252 \\
\hline Észak-Magyarország & 44,2 & 9,4 & 15,6 & 218 \\
\hline Közép-Magyarország & 0,1 & 38,3 & 22,2 & 311 \\
\hline Összesen & 100,0 & 100,0 & 100,0 & 1400 \\
\hline
\end{tabular}

Forrás: Országos Területfejlesztési Koncepció, 138-140. 0.; Illés I. 1997. 37. o. alapján Horváth Gy. számításai.

\section{Regionális fejlesztési stratégia és programozás}

Az Európai Unió és tagállamai regionális politikáját vizsgálva arra a következtetésre juthatunk, hogy a regionális politika az általános gazdaság- és társadalompolitika integráns, szerves része, a Közösségben e politika a gazdaságitársadalmi kohézió irányába ható erőfeszítések harmonizálására irányul.

A stratégiai célkitüzések hosszú távú prioritásgócok köré csoportosulnak (pl. az ipari versenyképesség javítása, a humán erőforrások, az idegenforgalom kiegyensúlyozott fejlesztése stb.), az állami finanszirozás ezekre összpontosul.

A regionális politika másik fontos ismertetőjegye, hogy hatóköre az ország egészére kiterjed, az érdekelt szervek ugyanis tisztában vannak a régiók közötti multiplikációs hatásokkal, emiatt lehetetlen stratégiai szempontból „szigetekre" tagolni az országot. Az egyes országokban a beavatkozás formáját és intenzitását természetesen a különbözö régiók sajátosságai alakitják, figyelembe véve azt az alapelvet, hogy nem csak a nehézségek terjedelmét (pl. az ipari válságtérséget), hanem a prioritások teljes választékát is tekintetbe kell venni.

Magyarországon, az előbbiekkel ellentétben, eddig a regionális politika másfajta felfogása érvényesült. Regionális politikán, vagy bizonyos régiók (telepulléscsoportok) életébe való jótékony gazdasági beavatkozást, vagy telepullésszintü szükségletek megnyugtató kielégitését értik. Ez a felfogás viszont csak a helyi szimptómák regisztrálására, semmint az „egész test betegségének” a gyógyítására alkalmas. 
Az elözöekböl Magyarország számára az alábbi következtetések adódnak:

- a regionális politikát az általános gazdaságpolitika integráns részeként kell kidolgozni;

- tervezési és fejlesztési szempontból az egész országot le kell fedni. Az átfogó tervezés sokszoros haszonnal jár, növeli az ágazati és a regionális programok hatékonyságát. Nyilvánvaló azonban, hogy az ország teljes lefedése nem jelenti az erőforrások homogén elosztását;

- az ágazati és a regionáiis célok között folyamatos tervezési és végrehajtási kölcsönkapcsolatot kell biztosítani.

Mivel az eladósodott, hosszabb távon tarthatatlanul nagy a fizetési mérleg és az államháztartás hiánya, az infláció magas, ezért elkerülhetetlen, hogy rövidebb és hosszabb távon eltérőek legyenek a területfejlesztési politika súlypontjai és prioritásai. Ezek nem kizárólagosak: a rövidebb táv prioritásai nem lehetetleníthetik el a hosszabb távú célok érdekében teendő lépéseket és megfordítva.

A középtávon prioritást élvezö célokat a következökben foglaljuk össze:

- azokban a térségekben, ahol a gazdasági növekedés már megindult vagy küszöbön áll, az intézményi és technikai akadályok elháritása (tulajdonrendezés, infrastrukturális szük keresztmetszetek oldása), illetve a vállalkozástámogatós generális eszközeinek alkalmazása a cél;

- az akut szociális és foglalkoztatási válsághelyzetek kezelése. Az elkerülhetetlen segélyezés és rászorultsági alapú támogatás mellett már ebben a szakaszban is növekvő szerepet játsszon az oktatás és átképzés, a települési infrastrukturális, környezetvédelmi és szociális célokat szolgáló közérdekü munka, valamint - a legkilátástalanabb esetekben - a népesség ésszerü arányú és irányú migrációjának elösegítése;

- a strukturális válság regionális csomópontjaiban koncentrált intervencióval a szerkezeti váltást elinditani (mindenekelött a bányászat, a kohászat, a hadiipar, a ruházati ipar fö telephelyein, valamint a mezőgazdasági termelés alacsony versenyképességü vagy piacait elveszitett körzeteiben);

- a területi társadalmi, demográfiai és etnikai szegregáció mérséklésére irányuló célkitüzések és a belső fejlödési adottságokra alapozott, adekvát területi mobilitási politika megfogalmazása.

A területfejlesztés hosszú távon érvényesithetõ prioritásai:

- a gazdasági tevékenység térbeli struktúrájának minél nagyobb mértékủ összehangolása a fenntartható fejlōdés követelményeivel, az egyes térségek természeti, környezeti potenciáljával, megtartva a történelmi települési struktúra megörzésre érdemes értékeit, vonásait és figyelembe véve a tájalakítás esztétikai szempontjait;

- a különbözö területeken és településekben élỏ közösségek számára minél nagyobb esélyegyenlöség teremtése, mind a gazdasági tevékenységben, vállalkozási lehetöségben, mind a munkával és kockázatvállalással arányos jövedelmekben és civilizatorikus életkörülményekben;

- annak biztositása, hogy Magyarország régiói, nagyvárosai, különböző szintủ és funkciójú centrumtelepülései integrálódjanak az európai térségbe és elfoglalják az egyenrangú munkamegosztás alapján alakuló funkcióikat az 
európai városhálózatban, megteremtve egyúttal az ország földrajzi helyzete által lehetővé tett szállítási, kommunikációs, idegenforgalmi pozíciót és európai szintü regionális centrumfunkciók előfeltételeit.

A megváltozott jelleget, funkciókat figyelembe véve a magyar területfejlesztési politika céljai belátható távon a következőkben foglalhatók össze:

- a térbeli és települési szerkezet olyan irányban való változtatása, formálása, amely alapot, keretet nyújt a hatékony, innovatív és versenyképes vállalkozási, gazdasági tevékenység számára és ezáltal hozzájárul a gazdaság dinamizálásához, a jövedelemtermelés növekedéséhez;

- a társadalmi és gazdasági esélykülönbségek csökkentése, a nagyobb területi egységek, illetve a településtípusok szintjén a civilizációs és infrastrukturális feltételek közelitése, valamint a súlyosan leszakadó térségek, települések szociális problémáinak kezelése;

- olyan programozási módszerek, eszközök és intézmények kialakitása, amelyek a megfelelô kiterjedésủ térségre, hatásterületre koncentrálva képesek a strukturális válságjelenségek korai felismerésére, kezelésére és igy hozzá tudnak járulni azok megoldásához;

- elősegiteni a gazdasági fejlödés térségi - humán, természeti és egyéb eröforrásainak mozgósitását, hasznosítását;

- mivel a piac által automatikusan nem szabályozható környezeti, föld- és területhasználati, a szükős erőforrásokon való osztozás kényszeréből fakadó ágazatkőzi konfliktusok elsősorban területi szinten keletkeznek, $a$ területfejlesztési politika különbözö ágazatok, tárcák és szakterületek közötti koordinációs szerepének ugyanolyan, vagy talán nagyobb a jelentősége, mint a makroszintü összehangolásnak;

- végül a határokon átnyúló együttmüködések és kapcsolatok elömozditása és ezáltal hozzájárulás a politikai határok által perifériális helyzetre itélt területek, települések lehetőségeinek, adottságainak jobb kihasználásához.

Meg kell kezdeni a támogatási rendszernek megfelelő területi tervek (programok) készitését:

- Az Országos Területfejlesztési Koncepciót Nemzeti Fejlesztési Tervvé (országprogrammá) kell átalakítani. Az aktualizálás mellett ki kell egésziteni a makrogazdasági és az ágazati értékelésekkel és programokkal. Időhorizontja 7 év. Várhatóan az EU-ban a kővetkező programozási időszak 2000-2006 lesz, így nekünk is erre az idöhorizontra kell a programot készíteni;

- A Nemzeti Fejlesztési Tervben központi feladatként megjelenö fejlesztéseket operatív programokká kell formálni és kezdeményezni kell, hogy ezek beépüljenek az alsóbb szintü programokba. Az operativ programnak koordináltan tartalmaznia kell mindazokat az országos jelentőségü „akciókat” is, amelyeket a központi kormányzat egyedül vagy társfinanszírozásban kíván megvalósítani. Az időhorizont: a programoktól függ, de általában 2-3 év. Az elfogadott operatív programok költségvetési fedezetének meg kell jelennie az éves költségvetésben; 
- Az eddig elkészult és most készülö regionális fejlesztési koncepciókat át kell alakítani az Egységes Programozási Dokumentummal szemben támasztott követelményeknek megfelelően.

A területfejlesztési támogatási rendszert korszerüsíteni kell. Az EU támogatási irányelveit ma már a tagságtól függetlenül a hazai támogatási politikában is alkalmazni célszerü. A támogatások döntő részét nagyobb (minimum 0,5, de még inkább 2 Mrd-ot meghaladó) programokba kell szervezni, ezek vonhatók be racionálisan a társfinanszírozásba.

A programozás intézményrendszerének a területfejlesztési törvényben csak az alapelemei találhatók meg, a csatlakozáshoz az intézményrendszer funkciójának pontosítása, a szervezetrendszer egyértelmủ meghatározása szükséges.

\section{Az intézményrendszer fejlesztése}

Valamennyi szinten fontos feladat a területfejlesztési döntéshozó és végrehajtási szervezetek jogi természetének tisztázása, a szervezeti szabályok részletezése és pontosítása.

A területfejlesztési tanácsok jogi természetének tisztázása során különösen a müködés törvényessége feletti felügyelet, a gazdálkodás törvényességének ellenörzése, a csalások kiszürése, a tanácsok által hozott tervdöntések jogi természete, a tanácsi tagsággal együtt járó jogok és kötelességek, a müködés finanszírozása, a hozott elosztási döntésekkel szembeni jogorvoslat rendszere, a tanácsok müködésének nyilvánossága, a demokratikus kontroll lehetösége, a helyi partnerség mechanizmusa igényel egyértelmü szabályozást.

Ugyancsak generálisan rendezendö a területfejlesztési munkaszervezetek müködése. Meg kell határozni, hogy mely szinteken támogatja leginkább a kormányzat a munkaszervezetek kiépülését. A helyi szereplök munkaszervezet létesítésével kapcsolatos ellenállása miatti patthelyzetből kilépést csak a munkaszervezetek létrehozására irányuló határozott kormányzati ösztönzés eredményezhet, egyrészt a munkaszervezetek központi finanszírozásával, másrészt a szervezeti forma kidolgozásával, esetleg önálló jogi személyiséggel és feladatokkal való felruházással. Például a munkaszervezeteknek központilag meghatározott feladatai lehetnének a területi információs rendszerrel, a monitoringgal, a pályázatok elökészitésével kapcsolatban.

A munkaszervezetek létrehozása sürgető igény, hiszen az EU-alapokhoz való hozzáférés kulcskérdése a professzionális programok és az alkalmas menedzsment megléte. Állandó, megfelelö nagyságrendü, szakmailag felkészült munkaszervezetre különösen regionális szinten van szükség. Megyei szinten a megyei, megyei jogú városi önkormányzatok, kamarák szorosabb bekapcsolásával a munkaszervezet kiépitése, illetve a meglévő szervezetek megbízása egyszerübben, saját erővel, helyi dőntésekkel megoldható. A kistérségi társulások esetében a városoknak kellene nagyobb szerepet vállalniuk, illetve - hosszabb távon - elképzelhető, hogy a városi vonzáskörzetek, illetve kistérségek általános hatáskőrü társulásai jönnek létre, amelyek elláthatják a területfejlesztéshez kapcsolódó helyi feladatokat.

Rendkívül fontos, vélhetően hosszabb időt igénylő, sok konfliktussal járó feladat a kormányzati koordináció erősítése, amely tekintetében talán a legkritikusabb az EU véleménye, annak ellenére, hogy létezik az Országos Területfejlesztési Tanács. 
A tanács szerepe a törvény módositása nélkül is erősíthető valamelyest, például azzal, ha a résztvevốk magas szinten képviseltetnék magukat. Ezt ugyan a törvény elö́rja, hiszen a kormányzati oldalnak miniszteri rangban kellene részt vennie a munkában, de a gyakorlat ezzel ellentétes. A területfejlesztési törvény önmaga is ellentmondást tartalmaz, hiszen elvileg felhatalmazza a tanácsot döntéshozásra is, de a törvény szövege alapján erre csak a saját ügyrendjének elfogadása és miniszteri kifogás esetén a megyei területfejlesztési tanács új eljárásra felhívása kérdésében van lehetőség;

- A tanács tényleges megerősítése a törvény módositásával tehát ügydöntö, egyetértési jogosítványok adásával és/vagy az elnöklés, illetve tárcakapcsolódás megváltoztatásával (miniszterelnök, illetve Miniszterelnöki Hivatal) lehetséges, a tárcák közti koordináció egy tárca kompetenciájába nem adható;

- Csak egy megerősitett OTT lesz alkalmas a nemzeti területfejlesztési tervezés és programozás, valamint a finanszírozás koordinációjára is. A tanács mellett kellene kialakitani a Központi Területfejlesztési Monitoring Bizottságot;

- A tanács szervezetének, fúggelmi viszonyainak a módositása érintheti a KTM pozícióját, hatáskörét, de ezt a kormányzati regionális politikai koordináció érdekének alárendelve lehet végiggondolni.

A területi és a központi intézményrendszernek egyaránt komoly hiányossága a területi információs rendszerek szervezeti és müködési megoldásainak kialakulatlansága, szabályozatlansága, annak ellenére, hogy kormányrendelet már megjelent a kérdésben. Sokan vitatják a területi információs rendszer megyei föjegyzöi hatáskörét. Ez feltétlenül újra gondolandó, hiszen a KSH alkalmasabbnak tủnik a feladatra, illetve a területfejlesztési tanácsok később megerösödő menedzsmentje is jobb megoldás lehet. Az EU-konform statisztikai rendszer alapvetỏen a nemzeti statisztikai hivatalokra támaszkodik, az információs rendszer egyébként sem lehet helyi belátás, kezdeményezés, önállóság kérdése. Megnyugtatóbb lenne egy tisztán állami bázisú statisztikai szervezeti rendszer müködtetése.

Hosszabb távon mérlegelendő a területfejlesztési intézményrendszer és a közigazgatási, illetve önkormányzati rendszer közötti viszony új alapokra helyezése, egy esetleges teruleti reform. Ennek a regionális politika szempontjából azért van jelentősége, mert az eddigi tapasztalatok szerint előnyt élveznek a közigazgatással kompatibilis programozási-fejlesztési régiók, politikai legitimitást birtokolva, illetve a regionális politika ágazati koordinációja is egyszerübb a közigazgatással kompatibilis területfejlesztési intézményrendszer esetén:

- Hosszabb távon elképzelhető, hogy a régiók nem csak a területfejlesztés, hanem egyre szélesebb állami-önkormányzati szerepvállalás kereteivé válnak, ami érinti a megyék jövöjét, mégpedig nyilvánvalóan a funkcionális gyengülés irányában;

- Reálisabb alternatívának tünik azonban a megyék politikai megerösödése, amely viszont azzal jár, hogy megszüntethető megyei szinten a megkettőzött területfejlesztési döntési rendszer, s az érdemi hatáskörök visszakerülnek a megyei önkormányzatokhoz. 
Ugyancsak több időt igényel a területfejlesztési tevékenységet alapvetően jellemző partnerségi, horizontális kapcsolatokra tekintettel az ún. közjogi vagy tervszerzödések rendjének kidolgozása, amelyek képesek a tervhierarchiát és redisztributív elosztást mellözve a partnerek tevékenységét elöre koordinálni, kiszámíthatóvá tenni, ami egyben a programozás, de különösen a forráskoncentráció jogi keretévé is tehető.

\section{Jegyzetek}

${ }^{1}$ Az Integrációs Stratégiai Munkacsoport és a 11., 18/3. sz. Európai Integrációs Tárcakőzi Bizottság részére készitett tanulmányok osszefoglalása. A vizsgálatokban közremúkoodott: Balogh András, Balázs István, Csatári Bálint, Csefkó Ferenc, Faragó László, Hajdú Zoltán, Horváth Gyula, Hrubi László, Illés Iván, Lados Mihály, Lőrincz Lajos, Novotnik Imre, Pálné Kovács Ilona, Perger Éva, Péteri Gábor, Rechnitzer Jảnos, Szigeti Ernō.

\section{Irodalom}

Agenda 2000. For a Stronger and Wider Union. Brussels, Eurpean Commission, 1997.

Alden, J.-Boland, Ph. (szerk.) (1996) Regional Development Strategies. A European Perspective. London, Jessica Kingsley Publ.

Anderson, J.J. (1992) The Territorial Imperative. Pluralism, Corporatism, and Economic Crisis. Cambridge, Cambridge University Press.

Armstrong, H. W.-Vickerman, R. W. (szerk.) (1995) Convergence and Divergence Among European Regions. London, Jessica Kingsley Publ.

Artobolevskiy, S. S. (1997) Regional Policy in Europe. London, Jessica Kingsley Publ.

Bachtler, J.-Michie, R. (1993) The restructuring of regional policy in the European Community. Regional Studies. 8. 719-725. o.

Bachtler, J.-Horvath, Gy. (1994) Strong and Weak Sides of the Hungarian Regional Policy. Glasgow, University of Strathclyde, European Policy Research Centre.

Basic Statistics of the Community. Brussels, EC, (1993)

Begg, I. (1997) Reform of the Structural Funds after 1999. European Planning Studies. 5. 675-690. o.

Blacksell, M.-Williams, A.M. (szerk.) (1994) The European Challenge. Geography and Development in the European Community. Oxford, Oxford University Press.

Clout, H. (1986) Regional Variations in the European Community. Cambridge, Cambridge University Press.

Cohesion in the European Union. Brussels, EC, (1996)

Coleman, W.D.-Jacek, H.J. (szerk.) (1989) Regionalism, Business Interests and Public Policy. London, SAGE Publications.

Commission Oppinion on Hungary's Application for Membership of the European Union. Brussels, European Commission, (1997)

Competitiveness and Cohesion. Trends in the Regions. Brussels, EC, (1994)

Definition and Limits of the Principle of Subsidiarity. Strasbourg, Council of Europe, 1994

Dunford, M.-Kafkalas, G. (szerk.) (1992) Cities and Regions in the New Europe. London, Belhaven Press.

Enyedi Gy. (1993) Társadalmi-területi egyenlötlenségek és teruleti politika Magyarországon. Enyedi Gy. (szerk.): Társadalmi-területi egyenlötlenségek Magyarországon. Bp., Közgazdasági és Jogi Konyyviadó. 9-21. o.

Enyedi Gy.-Pálné Kovács I. (1994) A kormány és az onkormányzatok. Gombár Cs.-Lengyel L. (szerk.): Kormány a mérlegen. Bp., Pénzägykutató Rt. 231-246. 0.

Enyedi Gy. (1996) Regionális folyamatok Magyarországon az átmenet idôszakában. Bp., Hilscher Rezső Szociálpolitikai Egyesulet.

ERDF in Figures, 1975-1988. Brussels, EC, 1989

Europe 2000: Outlook for the Development of the Community's Territory. Brussels, CEC, 1991.

Europe 2000: Cooperation for European Territorial Development. Brussels, EC, 1994. 
The European Union: Cohesion and Disparities. Brussels, EU, 1996.

Faragó L. (1993) Területfejlesztés - fantom vagy realitás? Kovács K. (szerk.): Település, gazdaság. igazgatás térben. Pécs, MTA Regionális Kutatások Kozpontja. 77-92, o.

Faragó L. (1997) Tervezéselméleti alapvetések. Tér és Társadalom. 3. (megjelenés alatt).

First Report on Economic and Social Cohesion. Brussels, EC, 1996.

General Report on the Activities of the European Union, 1994. Brussels, EC, 1995.

Geshev, G. (szerk.) 1997: Geografskoto prostranstvo - investicija za XXI vek. Sofija, Bolgarska Akademija na Naukite, Geografski Institut.

Gorzelak, G.-Kuklinski, A. (szerk.) (1992) Dilemmas of Regional Policies in Eastern and Central Europe. Warsaw, University of Warsaw. European Institute for Regional and Local Development.

Gorzelak, G. (1996) The Regional Dimension of Transformation in Central Europe. London, Jessica Kingsley Publ.

Green Paper on Regional Development of Romania. Bucharest, Government of Romania, 1997.

Grundlagen einer Europäischer Raumentwicklungspolitik. Bonn, Bundesministerium für Raumordnung, Bauwesen und Stădtebau, 1995.

Horváth Gy. (1992) A magyar regionális politika súlypontjai. Tér és Társadalom. 1-2, 1-19. o.

Horvath Gy. (szerk.) (1995) Reform of the Hungarian Regional Development Fund. Pécs, Centre for Regional Studies, European Policies Research Centre of the University of Strathclyde.

Horváth Gy. (1996) A magyar regionális politika és az európai kihivások. Vezetéstudomány. 1. 17-29. o.

Horváth Gy. (1997a) Regionális átalakulás és tơrvénykezés. Magyar Tudomámy. L. 3-14. o.

Horváth Gy. (szerk.) (1997b) Régiók felemelkedése és hanyatlása. Regionális átalakulás a Brit-szigeteken. Pécs, MTA Regionális Kutatások Központja.

Horváth Gy.-Illés I. (1997) Regionális fejlödés és politika. A gazdasági és a szociális kohézió erösitésének feladatai Magyarországon az Európai Unióhoz való csatlakozás időszakában. Bp., Európai Tükör Mühelytanulmányok, 16.

Illés I. (1996a) Regionális politika: felzárkózás vagy lemaradás. Európai Tükör. 1. 21-33. o.

Illés I. (1996b) Az onkormányzati rendszer finanszirozásának reformja Info-Társadalomtudomány. 37. o. 33-49. o.

Illés I. (1997) Elönyøok és hátrányok a regionális politikában. Európai Tükōr. 4. 21-40, o.

The Impact of Structural Policy on the Union's Economic and Social Cohesion, 1989-1999. Brussels, EC, 1996.

The Impact on Cohesion of the EU Enlargement. Glasgow, University of Strathclyde, EPRC, 1996.

The Implementation of the Reform of the Structural Funds in 1993. Fifth Annual Report. Brussels, EC, 1995.

Lengl T. (1997) „Miből fizetik a révészt?” Az EU struktúrapolitikai alapjainak szerepe a regionális egyenlôtlenségkezelésben. Pécs, JPTE Közgazdaságtudományi Kara. Szakdolgozat.

Nemes Nagy J. (1991) Regionális politika új feltételek között. Tér és Társadalom. 1. 89-103. o.

Nemes Nagy J. (1994) A magyar területi gazdaság adatai. Bp., Kézirat.

Országos Teruletfejlesztési Koncepció. Bp., A Magyar Köztársaság Kormánya. 1997. július.

Pálné Kovács I. (1995) A megyereformok ellentmondásai. Társadalmi Szemle. 1. 41-50. o.

Pálné Kovács I. (1997) Helyi onkormányzatok és a végrehajtó hatalom. Glatz F. (szerk.): A demokrácia intézményrendszere Magyarországon. Bp., Magyar Tudományos Akadémia. 115-130. 0.

Rechnitzer J. (1995) Tơprengések a teruleti szintū stratégiai tervezésröl. Tér és Tärsadalom. 3-4. 91-109. 0.

Rechnitzer J. (1996) A regionális folyamatok sajátosságai és jōvöbeli fejlödési irányai. Magyar Tudomány. 11. 1347-1360. 0.

Regionalnata politika $v$ Republika Bölgarija. Priobrastavane kōm evropejskija opit. Sofija, Ministerstvo na Teritorialnoto Razvitie i Stroitelstvo, 1996.

Regional Problems and Policies in the Czech Republic and the Slovak Republic. Paris, OECD, 1996.

Regions. Statistical Yearbook. Luxemburg, Eurostat, 1994.

Sadler, D. (1992) The Global Region. Production, State Policies and Uneven Development. Oxford, Pergamon Press.

Structural Funds and Cohesion Fund, 1994-99. Regulations and Commentary. Brussels, EC, 1996.

Structural Policy in Roland from the Perspective of Integration with the European Union. Warsaw, Task Force for Struktural Policy in Poland, 1997.

Yuill, D.-Bachtler, J. et al. (1995) European Regional Incentives, 1995-1996. London, Bowker-Saur. 


\section{ENLARGEMENT OF THE EUROPEAN UNION AND THE HUNGARIAN REGIONAL POLICY}

\section{GYULA HORVÁTH}

The policies of the European Communities established for the adjustment of macroeconomic processes have been transformed as consequence of economic development and subsequent enlargement of the EC. The joining of the Mediterranean countries resulted in increasing regional differences from the 1980ies on. For this reason, the main purpose of the policy reforms was the acceleration of the integration process and strengthening the cohesion inside the Community. Major emphasis was put on regional development in terms of policies and financial funds. The latter was given a new framework by enhancing and reforming the Structural Funds.

In the next phase of reforms, cohesion problems and expenses resulted by the eastern enlargement of the EU will be considered. In the future, only poorly performing areas and regions suffering from deficiencies of their economic structure or the inadequacy of labour resources may expect assistance from the EU. The new, eastern members for their general backwardness will absorb a substantial part of the available financial support. The centres of economic development are the capitals and regions of major cities in the Poland, the Czech Republic and Hungary. The losers of the transition period are rural regions and industrial districts having deficient economic basis. National governments will be the mediators of the EU assistance in diminishing spatial differences.

The applicant countries have to face with the need for the adjustment of their regional policies, administration and institutions. Hungary is in the most advanced position in terms of legislative framework, its compatibility with the EU regulations and the establishment of institutions of the regional policy. The weaknesses of the Hungarian system are the lacking division of duties and competence among institutions that should be clarified; the unsettled form of the NUTS II level in regional planning, contradictions of the NUTS IV level and the insufficiency of the professional staff of regional development councils. In the future, reform of financial framework, formation of EU-compatible regions, transformation of recent mechanism of distribution, incorporation of regional policy into governmental economic policies and development of the institutional system must be implemented to preserve the favourable position of Hungary amongst the applicant countries. 